\title{
Extraction Process, Component Analysis, and In Vitro Antioxidant, Antibacterial, and Anti-Inflammatory Activities of Total Flavonoid Extracts from Abutilon theophrasti Medic. Leaves
}

\author{
Chunlian Tian (iD, Peng Zhang, Caixia Yang, Xiang Gao, Hong Wang, Yuru Guo, \\ and Mingchun Liu
}

Key Laboratory of Zoonosis of Liaoning Province, College of Animal Science and Veterinary Medicine, Shenyang Agricultural University, No. 120 Dongling Road, Shenhe District, Shenyang, Liaoning Province 110866, China

Correspondence should be addressed to Mingchun Liu; liumingchun@sina.com

Received 7 November 2017; Revised 4 January 2018; Accepted 24 January 2018; Published 13 March 2018

Academic Editor: Adone Baroni

Copyright ( $\odot 2018$ Chunlian Tian et al. This is an open access article distributed under the Creative Commons Attribution License, which permits unrestricted use, distribution, and reproduction in any medium, provided the original work is properly cited.

\begin{abstract}
The flavonoid fraction was extracted from the leaves of Abutilon theophrasti Medic., which are usually used as a traditional Chinese herbal medicine for the treatment of inflammation and joint pain. The current study focused on the extraction process, component analysis, and in vitro antioxidant, antibacterial, and anti-inflammatory activities of the flavonoid fraction as a part of ongoing research on bioactive substances from natural plant sources. This study evaluated the antioxidant activities via assays of DPPH radical scavenging capacity, ABTS radical scavenging capacity, and reducing power and investigated inhibitory activities against Escherichia coli, Salmonella, Staphylococcus aureus, and Streptococcus. Moreover, the inflammatory activity of the flavonoid fraction was estimated by measurement of the content of tumor necrosis factor alpha, interleukin-1-beta, interleukin-6, interleukin-10, nitric oxide, and cyclooxygenase- 2 and the gene expression levels of several inflammation markers, such as inducible nitric oxide synthase and cyclooxygenase-2, in RAW 264.7 macrophages after LPS treatment. In addition, the underlying anti-inflammatory mechanisms, that is, the activation of nuclear factor kappa B (NF- $\kappa \mathrm{B})$ and mitogen-activated protein kinase (MAPK) signaling pathways, were also revealed from the gene and protein expression levels. Taken together, these results suggested that the flavonoid fraction might exert in vitro antioxidant, antibacterial, and anti-inflammatory effects on LPS-stimulated RAW 264.7 macrophages and will be potentially useful as an adjuvant treatment for oxidative stress and bacterial and inflammatory diseases.
\end{abstract}

\section{Introduction}

Oxidative stress, which is an important factor that leads to aging and diseases, can be produced by excessive free radicals [1-4]. Therefore, the elimination of harmful free radicals is an effective approach for balancing the internal environment and preventing related diseases. Synthetic antioxidants, such as butylated hydroxytoluene (BHT) and butyl hydroxy anisd (BHA), have been applied widely in the food, pharmaceuticals, cosmetic, and manufacturing industries. However, studies have shown that these antioxidants produce adverse reactions, resulting in diseases and behavioral changes $[5,6]$.

Furthermore, the body's resistance declines and is accompanied by the various influential factors, including old age, diabetes, liver cirrhosis, cancer, blood diseases, chemotherapy, radiotherapy, immune suppressants, hormones, and antibiotics. Under these circumstances, the body is vulnerable to bacteria, even those that are weakly pathogenic. Therefore, antibiotics are usually a first choice for treatment of infectious diseases induced by bacterial or pathogenic microorganisms. However, their adverse effects, such as anaphylaxis $[7,8]$, intestinal flora alteration $[9,10]$, and, in particular, drug resistance $[11,12]$, are often overlooked.

In addition, inflammation, which is a major defense reaction of the immune system [13] to harmful stimuli, including infection and injury, is a serious threat to health $[14,15]$ and exists in many diseases, such as bronchitis, pneumonia, gastritis, nephritis, and rheumatism. At present, steroidal and 
nonsteroidal anti-inflammatory drugs are commonly used in clinics; nevertheless, their side effects, such as gastrointestinal tract damage [16,17] and allergic reactions [18-20], cannot be ignored.

Briefly, oxidative damage, bacterial infection, and inflammation are relatively typical clinical symptoms in many diseases. However, increasing attention has been given to adverse drug reactions. Therefore, it is necessary to carry out research for the development of natural, green pharmaceuticals.

Abutilon theophrasti Medic. (A. theophrasti) is grown widely in the tropics and subtropics, such as China, Vietnam, India, Japan, Europe, and North America [21], and is rich in potentially important bioactive compounds, including flavonoids, phenolics, organic acids, polysaccharides, saponins, amino acids, and coumarin [22-24]. Moreover, this plant has been utilized in folk treatments for ulcers, swell, venom, inflammation, and pain [25-27]. However, the antioxidant, antibacterial, and anti-inflammatory activities of $A$. theophrasti leaves have not been extensively investigated.

Preliminary studies showed that A. theophrasti roots, stems, leaves, seeds, and episperm are rich in flavonoids and that the leaves contain the highest content of total flavonoids [24]. It is well known that flavonoids have a wide range of biological activities and pharmacological effects, such as antioxidant, antibacterial, anti-inflammatory, anticancer, and antiviral activities and effects [28-33]. To evaluate the therapeutic potential of the flavonoid fractions of medicinal herbs, $A$. theophrasti leaves, traditionally used in China, were studied for their antioxidant, antimicrobial, and anti-inflammatory activities against free radicals, pathogenic bacteria, and inflammation induced by LPS in RAW 264.7 cells. Moreover, anti-inflammatory mechanisms were further revealed by analysis of the expression of genes and proteins that are associated with nuclear factor kappa B $(\mathrm{NF}-\kappa \mathrm{B})$ and mitogen-activated protein kinase (MAPK) signaling pathways.

Therefore, the objectives of this paper were (a) to investigate the process of extracting the flavonoid fraction of $A$. theophrasti leaves by single-factor experiments and response surface method; (b) to identify the chemical components in the extract by HPLC-DAD-ESI-MS ${ }^{\mathrm{n}}$; (c) to evaluate the in vitro antioxidant, antibacterial, and anti-inflammatory activities of the total flavonoid extract (TFE); and (d) to analyze the anti-inflammatory mechanisms that are associated with the NF- $\kappa \mathrm{B}$ and MAPK signaling pathways.

\section{Materials and Methods}

2.1. Plant Collection. A. theophrasti leaves were collected from Jilin Province of China in August, September, and October (numbers 1408, 1409, and 1410, resp.) and were authenticated by Professor Jingming Jia of Shenyang Pharmaceutical University according to the Compendium of Materia Medica. The voucher specimens KT/JL/CH/AT/08/ 14, $\mathrm{KT} / \mathrm{JL} / \mathrm{CH} / \mathrm{AT} / 09 / 14$, and $\mathrm{KT} / \mathrm{JL} / \mathrm{CH} / \mathrm{AT} / 10 / 14$ were deposited at our laboratory for future reference. The leaves were washed and dried in a shady and dry place at room temperature for 30 days and were then ground to a fine powder before extraction.

2.2. Chemicals and Reagents. 2,2'-Azino-bis(3-ethylbenzothiazoline-6-sulfonic acid diammonium salt) (ABTS), 2,2diphenyl-1-picrylhydrazyl (DPPH), and 2,4,6-tri(2-pyridyl)-s-triazine (TPTZ) were purchased from Sigma-Aldrich Chemie (Steinheim, Germany). Escherichia coli lipopolysaccharide (LPS), dimethyl sulfoxide (DMSO), and 3-(4,5-dime thylthiazol-2-yl)-2,5-diphenyltetrazolium bromide (MTT) were purchased from Sigma-Aldrich (St. Louis, MO, USA). Interleukin-1 beta (IL-1 $\beta$ ), IL-6, IL-10, and tumor necrosis factor alpha (TNF- $\alpha$ ) Elisa kits were obtained from eBioscience (Science Center Drive San Diego, CA, USA). COX-2 Elisa kit was purchased from Axygen (Central Avenue Union City, CA, USA). Antibodies against $\mathrm{I} \kappa \mathrm{B} \alpha, \mathrm{p}-\mathrm{I} \kappa \mathrm{B} \alpha$, NF- $\kappa$ B p 65, p-NF- $\kappa$ B p 65, p $38 \alpha$, p-p38 $\alpha, J N K 1 / 2$, p-JNK1/2, ERK1/2, p-ERK1/2, and $\beta$-actin were purchased from Santa Cruz Biotechnology (Santa Cruz, CA, USA), and secondary antibodies were obtained from Sangon Biotech (Shanghai, China). Other chemicals and reagents were all analytically pure and obtained from Sinopharm Chemical Reagent Co. Ltd. (Shanghai, China).

2.3. Instruments. LC-MS/MS analysis was performed on an Agilent 1100 series HPLC (Palo Alto, CA, USA) equipped with a G1311A quaternary pump, a G1313A highperformance autosampler, a G1379A in-line degasser, and a G1316A thermostatted column compartment. The mass spectrometer was an Agilent Ion Trap MSD SL instrument equipped with an atmosphere pressure chemical ionization (APCI) source coupled with an electrospray ionization (ESI) interface. Instrument operation, data acquisition, and processing were performed by MassHunter Workstation software (version B.03.01, Agilent). Chromatograph separation was carried out by liquid chromatography coupled to diode array detection (LC-DAD) analysis. UV spectra were recorded in a range of $210-400 \mathrm{~nm}$ and monitored at $350 \mathrm{~nm}$.

2.4. Preparation of Extract. A suitable amount of A. theophrasti leaf powder was accurately weighed and extracted with a $42.28 \%$ ethanol solution, a $30: 1(\mathrm{ml} / \mathrm{g})$ ratio of solvent to material, and an ultrasonic-assisted extraction time of $30 \mathrm{~min}$ at room temperature. The extraction solution was first filtered through quantitative filter paper, and the medicinal material residue was further extracted one time by using the same extraction solvent, ratio of solvent to material, and ultrasonic-assisted extraction time. The two filtrates were pooled together and then evaporated to yield a solid residue by rotary evaporator. The solid residue was dissolved with a proper solvent and stored in a refrigerator $\left(4^{\circ} \mathrm{C}\right)$ until used for analysis.

2.5. Total Flavonoid Content. Total flavonoid content (TFC) was measured by a colorimetric method [34] with minor modifications, and rutin was used as a standard. The chromogenic reaction system consisted of aluminum nitrate, sodium nitrite, and sodium hydroxide. A total of $5 \mathrm{ml}$ of extract solution $(0.05 \mathrm{~g} / \mathrm{ml})$ was added in a $10 \mathrm{ml}$ volumetric flask and then mixed with $0.3 \mathrm{ml}$ of $5 \%$ sodium nitrite 
solution. After reaction for $6 \mathrm{~min}$ at room temperature, $0.3 \mathrm{ml}$ of $10 \%$ aluminum nitrate solution was added, and then, $4 \mathrm{ml}$ of $4 \%$ sodium hydroxide solution was added after reacting for another $6 \mathrm{~min}$. Finally, the volume of the reaction solution was increased to $10 \mathrm{ml}$ with ethanol. The reaction solution was mixed thoroughly and incubated for $20 \mathrm{~min}$ at room temperature. After high-speed centrifugation for $6 \mathrm{~min}$, the absorbance of the supernatant was measured at $510 \mathrm{~nm}$. TFC was defined as follows: extraction yield of total flavonoids $(w / w)(\%)=$ mass of total flavonoids expressed as mg of rutin equivalents per g dry weight of $A$. theophrasti leaf sample (mg RE/g DW). All tests were performed in triplicate, and the means were calculated.

\subsection{Flavonoids Compositions Analyzed by HPLC-MS}

2.6.1. Sample Preparation for HPLC-MS Analysis. A total of $0.5 \mathrm{~g}$ of $A$. theophrasti leaf powder was extracted with the optimum extraction conditions and dried by vacuum rotary evaporation to yield a solid residue. The solid residue was dissolved with $10 \mathrm{ml}$ of chromatographic methanol (Merck Serono Co. Ltd., Germany), centrifuged (2000 rmp), and filtered with a $0.22 \mu \mathrm{m}$ microfiltration membrane prior to LC-DAD and LC-MS analysis.

2.6.2. LC-MS/MS and LC-DAD Conditions and Parameters. The molecules were separated on a $\mathrm{C}_{18}$ column (Dikma platinum series, $250 \mathrm{~mm} \times 4.6 \mathrm{~mm}$, i.d. $5 \mu \mathrm{m}$ ) using the following mobile phase: (A) acetonitrile and (B) water formic acid $0.1 \%$. LC separation conditions consisted of an isocratic step at $0-45 \%$ of $\mathrm{A}$ for $0-45 \mathrm{~min}$ and then $45-0 \%$ of $\mathrm{A}$ for $45-$ $50 \mathrm{~min}$, with a flow rate of $700 \mu \mathrm{l} / \mathrm{min}$. The HPLC-ESI-MS/ MS operating conditions were as follows: negative and positive ion modes, automatic secondary mass spectrum scan with a scanning range of $50-1000 \mathrm{~m} / \mathrm{z}$, drying gas with $12 \mathrm{l} /$ min and $350^{\circ} \mathrm{C}$, nebulizer pressure of $30 \mathrm{psi}$, and a capillary voltage of $3500 \mathrm{~V}$.

For LC-DAD analysis, the same chromatographic conditions described for LC-MS/MS analysis were employed, with the exception of an injection volume of $20 \mu \mathrm{l}$.

\subsection{Determination of Chemical-Based Antioxidant Activities}

2.7.1. ABTS Radical Scavenging Activity Assay. The ABTS radical scavenging activity of TFE from $A$. theophrasti leaves was assayed by the method of Dawidowicz and Olszowy [35] with minor modifications. The ABTS radical cation $\left(\mathrm{ABTS}^{+}\right)$ was obtained in a reaction of $7 \mathrm{mmol} / \mathrm{l} \mathrm{ABTS}$ and $2.45 \mathrm{mmol} /$ 1 potassium persulfate. After the mixture was incubated at room temperature in the dark for $12-16 \mathrm{~h}$, the ABTS solution was diluted with PBS to obtain an absorbance of $0.700 \pm 0.02$ at $734 \mathrm{~nm}$. A total of $0.1 \mathrm{ml}$ of different concentrations of TFE was mixed with $0.9 \mathrm{ml}$ of the ABTS solution, and the absorbance of the resulting solution was measured at $734 \mathrm{~nm}$ after a $30 \mathrm{~min}$ incubation period at room temperature in a water bath in the dark. The scavenging effect was calculated by the following equation: radical scavenging rate $(\%)=\left[\left(A_{0}-A_{1}\right) / A_{\text {blank }}\right] \times 100 \%$, where $A_{0}$ and $A_{1}$ are the absorbance of the ABTS solution and ABTS solution with sample at different concentrations, respectively. The antioxidant activity was expressed as the $\mathrm{IC}_{50}(\mathrm{mg} / \mathrm{ml})$, which is the TFE concentration that inhibits $50 \%$ of the free radicals.

2.7.2. DPPH Radical Scavenging Activity Assay. The DPPH. radical scavenging activity of TFE was measured by the method described by [36] with modifications. A total of $0.1 \mathrm{ml}$ of different concentrations of sample was mixed with $0.9 \mathrm{ml}$ of $0.1 \mathrm{mmol} / 1 \mathrm{DPPH}$ radical ethanol solution. The mixture was shaken and incubated for $30 \mathrm{~min}$ at $37^{\circ} \mathrm{C}$ in a water bath in the dark, and the absorbance of the resulting solution was assayed at $517 \mathrm{~nm}$. The values of $\mathrm{IC}_{50}$ were determined as reported above.

2.7.3. Ferric-Ion Reducing Antioxidant Power Assay. The ferric-ion reducing antioxidant power (FRAP) of TFE was measured by the method of Pajak et al. [37] with modifications. Briefly, the FRAP reagent was a mixture of acetate buffer (pH 3.6), $20 \mathrm{mmol} / 1 \mathrm{FeCl}_{3}$, and $10 \mathrm{mmol} / \mathrm{l} \mathrm{TPTZ} \mathrm{in}$ $40 \mathrm{mmol} / 1 \mathrm{HCl}$ at $10: 1: 1(v / v / v)$. An aliquot of $0.1 \mathrm{ml}$ of different concentrations of TFE was added to $0.4 \mathrm{ml}$ of FRAP reagent, the solution was incubated in the dark for $30 \mathrm{~min}$ at $37^{\circ} \mathrm{C}$ in a water bath, and the absorbance was measured at $593 \mathrm{~nm}$. The values were expressed as mmol $\mathrm{Fe}^{2+}$ per $100 \mu \mathrm{g} / \mathrm{ml}$ of TFE. All determinations were performed in triplicate.

\subsection{Determination of Antimicrobial Activity}

2.8.1. Microbial Strains. The standard strains of Escherichia coli (ATCC 25922), Salmonella typhimurium (ATCC 51812), Staphylococcus aureus (ATCC 25923), and Streptococcus pneumoniae (ATCC 49619) were obtained from American Type Culture Collection and stored at the Department of Animal Pharmacy, College of Animal Science and Veterinary Medicine, Shenyang Agricultural University.

2.8.2. Bacterium Solution Preparation. Escherichia coli, Salmonella typhimurium, Staphylococcus aureus, and Streptococcus pneumoniae were inoculated onto MacConkey agar medium, SS agar medium, hypersalt mannitol medium, and improved Edward medium, respectively. For Streptococcus, rabbit blood (without fibrin) was added to the culture medium to produce a final concentration of $5 \%$. After overnight culture, the four standard strains were adjusted to 0.5 McFarland turbidity standards $\left(1 \times 10^{8} \mathrm{CFU} / \mathrm{ml}\right)$ and were then diluted to a ratio of $1: 1000$ with sterile nutrient broth.

2.8.3. Sample Solution Preparation for Antibacterial Activity Assay. TFE was prepared with optimal extraction technology and was dissolved in sterile water to obtain an initial stock solution concentration of $2.0 \mathrm{~g}$ of raw medicinal material/ ml. Ten serial twofold dilutions of the stock solution were prepared to produce a final concentration of 1.0 to $0.002 \mathrm{~g}$ of raw medicinal material $/ \mathrm{ml}$. The stock solution concentration of gentamicin was $1.28 \mathrm{mg} / \mathrm{ml}$, and the final concentration ranged from 0.25 to $128 \mu \mathrm{g} / \mathrm{ml}$.

2.8.4. Antibacterial Activity Assay. Antibacterial activity was screened by the microwell dilution method as described by Jaradat et al. [38] with modifications, and the MIC values, defined as the lowest concentration of samples showing clear 
wells or with complete inhibition of bacteria, were chosen as the primary evaluation indicators. Briefly, each well of a 96well plate was filled with $100 \mu \mathrm{l}$ TFE solution and $100 \mu \mathrm{l}$ of bacterium solution and was completely mixed. The plates were covered and incubated at $37^{\circ} \mathrm{C}$ for $24 \mathrm{~h}$. The antibiotic gentamicin and sterile water (in a similar volume as the test sample) were used as the positive and negative controls, respectively. Each experiment was performed in triplicate.

\subsection{Determination of Anti-Inflammatory Activity Assay}

2.9.1. Cell Culture. RAW 264.7 cells belonging to a murine macrophage cell line were purchased from the Shanghai Cell Bank of the Chinese Academy of Sciences (Shanghai, China). These cells were cultured in RPMI 1640 medium containing $10 \%$ fetal bovine serum, $100 \mathrm{U} / \mathrm{ml}$ penicillin, and a streptomycin mixture with supplemented $5 \% \mathrm{CO}_{2}$ at $37^{\circ} \mathrm{C}$.

\subsubsection{Sample Solution Preparation for Anti-Inflammatory} Activity. TFE solution was prepared with the optimized extraction process and was dissolved completely with RPMI 1640 medium at a final concentration of $13.14 \mathrm{mg} / \mathrm{ml}$. Then, TFE solution was filtered, packed, and preserved at $-20^{\circ} \mathrm{C}$ for later use.

2.9.3. Cell Viability MTT Assays. The cytotoxicity of TFE in RAW 264.7 cells was evaluated using the MTT assay based on the conversion of MTT into formazan crystals in living cells [39]. In brief, cells were cultured in 96-well plates with $4 \times 10^{4}$ cells/well until confluent. After one hour incubation, the cells were grouped into a negative control group, an LPS model group, and three test groups with final TFE concentrations of 50,100 , and $200 \mu \mathrm{g} / \mathrm{ml}$, respectively. Then, $50 \mu \mathrm{l}$ of LPS $(1 \mu \mathrm{g} / \mathrm{ml})$ was added to the LPS model group and three test groups, and $50 \mu \mathrm{l}$ of RPMI 1640 medium was added to the negative control group. After all groups were incubated for $18 \mathrm{~h}, 20 \mu \mathrm{l}$ of MTT reagent $(5 \mathrm{mg} / \mathrm{ml})$ was added, and each well was incubated for $4 \mathrm{~h}$. Then, $150 \mu \mathrm{l}$ of dimethyl sulfoxide was mixed after discarding the supernatant and shaken gently, followed by microplate reader detection at $570 \mathrm{~nm}$. Data are representative of three independent assays.

2.9.4. Measurement of COX-2 and NO. In total, $4 \times 10^{5}$ cells were seeded into 96-well plates. After incubation for $1 \mathrm{~h}$, $50 \mu \mathrm{l}$ of LPS $(1 \mu \mathrm{g} / \mathrm{ml})$ was added to the LPS model group and three test groups, and $50 \mu \mathrm{l}$ of RPMI 1640 medium was added to the negative control group. The supernatant was collected for measurement of COX-2 and NO after treatment for $18 \mathrm{~h}$.

(1) COX-2 Measurement. The content of COX-2 in the culture supernatant was quantified using an ELISA kit in accordance with the manufacturer's instructions. The OD values were measured at $450 \mathrm{~nm}$. After stop buffer is added, quantification must be completed within $15 \mathrm{~min}$.

(2) NO Measurement. To prepare solvent A, $1.0 \mathrm{~g}$ of anhydrous sulfanilic acid, $6 \mathrm{ml}$ of $85 \%$ phosphoric acid, and $70 \mathrm{ml}$ of deionized water were mixed and dissolved adequately, and then, the mixture was diluted to $100 \mathrm{ml}$ in a volumetric flask.

To prepare solvent B, $0.1 \mathrm{~g}$ of $n$-naphthylethylenediamine was dissolved fully in deionized water and diluted to a volume of $100 \mathrm{ml}$.

The NO content was assayed by the Griess reagent method with modifications described by Su et al. [40]. Briefly, $50 \mathrm{ml}$ of different concentrations of sodium nitrite standard diluents and the supernatant was reacted with $50 \mathrm{ml}$ of solvent $\mathrm{A}$ and incubated at $37^{\circ} \mathrm{C}$ for $10 \mathrm{~min}$. Then, $50 \mathrm{ml}$ of solvent $\mathrm{B}$ was added, and the mixture was incubated again at $37^{\circ} \mathrm{C}$ for $10 \mathrm{~min}$. After incubation, the absorbance was measured at $540 \mathrm{~nm}$. The concentration of $\mathrm{NO}$ was calculated from an established sodium nitrite standard curve. The data are representative of three independent experiments.

2.9.5. Measurement of Cytokine Secretion. The proinflammatory cytokines TNF- $\alpha$, IL- $1 \beta$, and IL- 6 and the antiinflammatory cytokine IL-10 from the supernatant of RAW 264.7 cell cultures were assayed by ELISA kits according to the manufacturer's instructions. Briefly, $100 \mu \mathrm{l}$ of diluted capture antibody was added to each well and incubated overnight at $4^{\circ} \mathrm{C}$. After the supernatant was discarded, the wells were washed 4 times with a special ELISA lotion. For each wash, the wells were soaked for approximately $1 \mathrm{~min}$, and the remaining fluid was subsequently removed with blotting paper. Next, $200 \mu \mathrm{l}$ of sample diluent was added to each well, and the plate was sealed with single-use sealing membrane and incubated for $1 \mathrm{~h}$ at $37^{\circ} \mathrm{C}$. Then, $100 \mu \mathrm{l}$ of eight different concentrations of standards and culture supernatant was added to each well and mixed with $100 \mathrm{ml}$ of diluted detection antibody, and the plate was then incubated for $1 \mathrm{~h}$ at $37^{\circ} \mathrm{C}$. After washing, $100 \mu \mathrm{l}$ of horseradish peroxidase was added, and the plate was sealed for a $30 \mathrm{~min}$ incubation. Then, $100 \mu \mathrm{l}$ of tetramethylbenzidine color developing agent was added and incubated for $15 \mathrm{~min}$. Finally, every well was reacted with $50 \mu \mathrm{l}$ of stop buffer, and absorbance was measured at $450 \mathrm{~nm}$ using a microplate reader. The cytokine concentrations were calculated from a standard curve on the basis of absorbance values.

2.9.6. Total RNA Extraction and Gene Expression Level Assay by Quantitative Real-Time PCR. Total RNA of RAW 264.7 cells was extracted with TRIzol reagent (Vazyme Biotech Co. Ltd., USA) according to the manufacturer's instructions, and gene expression levels were quantified by quantitative real-time polymerase chain reaction ( $\mathrm{qRT}$-PCR) as described previously [41]. PCR products were analyzed by a spectrophotometer (DU 730, Beckman Coulter, USA) and $1 \%$ agarose gel electrophoresis for quality control. The expression level of mRNA was analyzed using an IQTM5 Optical Module fluorescence quantitative gene amplification instrument (Bio-Rad, USA). RNA was reverse-transcribed into cDNA according to the operating instructions of the reverse transcription reaction system and was used as a template for amplification by PCR. The fluorescence qRT-PCR primer sequences (sequence $5^{\prime}-3^{\prime}$ ) are shown in Table 1 . After normalization with $\beta$-actin (internal control), fold changes in the expression levels of target mRNAs (COX-2, 
TABLE 1: The primer sequences of fluorescence qRT-PCR.

\begin{tabular}{|c|c|c|c|c|}
\hline Genes & Primer direction & Primer sequences $\left(5^{\prime}-3^{\prime}\right)$ & Reannealing temperature $\left({ }^{\circ} \mathrm{C}\right)$ & Product size (bp) \\
\hline \multirow{2}{*}{$C O X-2$} & Forward & AGCCAGGCAGCAAATCCTT & \multirow{2}{*}{60} & \multirow{2}{*}{169} \\
\hline & Reverse & GGGTGGGCTTCAGCAGTAAT & & \\
\hline \multirow{2}{*}{ iNOS } & Forward & GGTGAAGGGACTGAGCTGTT & \multirow{2}{*}{60} & \multirow{2}{*}{103} \\
\hline & Reverse & ACGTTCTCCGTTCTCTTGCAG & & \\
\hline \multirow{2}{*}{$I \kappa B$} & Forward & GCCATCCCAGGCAGTATCTA & \multirow{2}{*}{60} & \multirow{2}{*}{106} \\
\hline & Reverse & TTCCAAGACCAGACCTCCAG & & \\
\hline \multirow{2}{*}{ p65 } & Forward & GACCTGGAGCAAGCCATTAG & \multirow{2}{*}{60} & \multirow{2}{*}{123} \\
\hline & Reverse & CACTGTCACCTGGAAGCAGA & & \\
\hline \multirow{2}{*}{$p 38 \alpha$} & Forward & CTATGGCTCGGTGTGTGCT & \multirow{2}{*}{60} & \multirow{2}{*}{115} \\
\hline & Reverse & GACGCAACTCTCGGTAGGTC & & \\
\hline \multirow{2}{*}{$J N K$} & Forward & TGTTCCCCGATGTGCTTTT & \multirow{2}{*}{59.7} & \multirow{2}{*}{147} \\
\hline & Reverse & CGTTGATGTATGGGTGCTG & & \\
\hline \multirow{2}{*}{ ERK1/2 } & Forward & GCGGCTGAAGGAGTTGAT & \multirow{2}{*}{60} & \multirow{2}{*}{119} \\
\hline & Reverse & CAGGTAGGAGCAGGACCAGA & & \\
\hline \multirow{2}{*}{$\beta$-Actin } & Forward & GTGCTATGTTGCTCTAGACTTCG & \multirow{2}{*}{60} & \multirow{2}{*}{174} \\
\hline & Reverse & ATGCCACAGGATTCCATACC & & \\
\hline
\end{tabular}

iNOS, I $\kappa B, p 65, p 38 \alpha, J N K$, and $E R K 1 / 2)$ were calculated using the $2^{-\triangle \triangle \mathrm{CT}}$ method.

2.9.7. Protein Extraction and Western Blot Analysis. RAW 264.7 cells and test samples (final TFE concentrations of 50, 100 , and $200 \mu \mathrm{g} / \mathrm{ml}$ ) were incubated with RPMI 1640 medium for $1 \mathrm{~h}$ and then induced with LPS $(1 \mu \mathrm{g} / \mathrm{ml})$ for $30 \mathrm{~min}$. After the supernatant was discarded, the cells were washed twice with precooled PBS and then disrupted with a mixture of cell lysis buffer and phenylmethanesulfonyl fluoride $\left(v: v, 9: 1 ; 1.0 \mathrm{ml}\right.$ per well) for $2-3 \mathrm{~h}$ at $4^{\circ} \mathrm{C}$ for the extraction of total proteins. Cell lysates were centrifuged at $14,000 \times \mathrm{g}$ for $15 \mathrm{~min}$ at $4^{\circ} \mathrm{C}$, and then, the supernatant was collected for further analysis. The total protein concentration was measured by a BCA protein assay kit (CWBIO Biotechnology Co. Ltd., Beijing, China) according to the manufacturer's instructions.

The protein samples were separated by sodium dodecyl sulfate-polyacrylamide gel electrophoresis (SDS-PAGE) and transferred to polyvinylidene fluoride (PVDF) membranes (Solarbio Technology Ltd., Beijing, China). The PVDF membranes were blocked with 5\% skimmed milk in TBST buffer containing $0.05 \%$ Tween 20 for $1 \mathrm{~h}$ and then incubated for $2 \mathrm{~h}$ at $37^{\circ} \mathrm{C}$. Subsequently, the membranes were incubated sequentially at $4^{\circ} \mathrm{C}$ overnight with primary monoclonal antibodies, including $\mathrm{I} \kappa \mathrm{B} \alpha, \mathrm{p}-\mathrm{I} \kappa \mathrm{B} \alpha, \mathrm{NF}-\kappa \mathrm{B}$ p $65, \mathrm{p}-\mathrm{NF}-\kappa \mathrm{B}$ p 65 , p38 $\alpha$, p-p38 $\alpha, J N K 1 / 2$, p-JNK1/2, ERK1/2, p-ERK1/2, and $\beta$-actin (Santa Cruz Biotechnology Co. Ltd., USA). After washing 3-5 times, the membranes were incubated continuously with secondary antibodies labeled with horseradish peroxidase for $2 \mathrm{~h}$ at $37^{\circ} \mathrm{C}$. Finally, chemiluminescence detection was conducted using an ECL assay kit (Beyotime Biotechnology Co. Ltd., Shanghai, China), and the images were captured using a Micro Chemic Gel Doc XR (Bio-Rad,
TABLE 2: Independent variables and the levels used in the Box-Behnken design.

\begin{tabular}{lccc}
\hline \multirow{2}{*}{ Independent variables } & \multicolumn{3}{c}{ Levels } \\
& -1 & 0 & 1 \\
\hline Extraction time $(A, \mathrm{~min})$ & 20 & 25 & 30 \\
Concentration of ethanol solution $(B, \%)$ & 30 & 40 & 50 \\
Ratio of solvent to material $(C, \mathrm{ml} / \mathrm{g})$ & 20 & 25 & 30 \\
\hline
\end{tabular}

TABle 3: The Box-Behnken design matrix and response values for TFE yields.

\begin{tabular}{llccc}
\hline Run & \multicolumn{3}{c}{ Variable levels } & $\begin{array}{c}\text { Response 1 } \\
(\mathrm{R} 1)\end{array}$ \\
\hline 1 & $\mathrm{~A}$ & $\mathrm{~B}$ & $\mathrm{C}$ & 1.09 \\
2 & 25 & 40 & 25 & 1.04 \\
3 & 20 & 30 & 25 & 1.02 \\
4 & 20 & 40 & 20 & 1.02 \\
5 & 30 & 30 & 25 & 1.21 \\
6 & 25 & 30 & 30 & 1.17 \\
7 & 30 & 40 & 20 & 1.29 \\
8 & 30 & 40 & 30 & 1.08 \\
9 & 25 & 40 & 25 & 1.16 \\
10 & 20 & 40 & 30 & 1.09 \\
11 & 25 & 40 & 25 & 1.09 \\
12 & 25 & 50 & 30 & 0.85 \\
13 & 20 & 50 & 25 & 1.08 \\
14 & 25 & 40 & 25 & 1.07 \\
15 & 25 & 50 & 20 & 1.18 \\
16 & 30 & 50 & 25 & 1.00 \\
17 & 25 & 30 & 20 & 1.09 \\
\hline
\end{tabular}


TABLE 4: ANOVA for the response surface quadratic model of TFE yields.

\begin{tabular}{|c|c|c|c|c|c|c|}
\hline Source & Sum of squares & $\mathrm{DF}$ & Mean square & $F$ value & $p$ value, prob $>F$ & Significant \\
\hline Model & 0.15 & 9 & 0.017 & 299.31 & $<0.0001$ & Significant \\
\hline$A$ & 0.044 & 1 & 0.044 & 771.11 & $<0.0001$ & $* *$ \\
\hline$B$ & 0.0008 & 1 & 0.0008 & 14.18 & 0.0070 & $* *$ \\
\hline$C$ & 0.030 & 1 & 0.030 & 531.87 & $<0.0001$ & $* *$ \\
\hline$A B$ & 0.031 & 1 & 0.031 & 542.72 & $<0.0001$ & $* *$ \\
\hline$A C$ & 0.0001 & 1 & 0.0001 & 1.77 & 0.2248 & \\
\hline$B C$ & 0.009025 & 1 & 0.009025 & 159.94 & $<0.0001$ & $* *$ \\
\hline$A^{2}$ & 0.00001684 & 1 & 0.00001684 & 0.30 & 0.6018 & \\
\hline$B^{2}$ & 0.018 & 1 & 0.018 & 320.13 & $<0.0001$ & $* *$ \\
\hline$C^{2}$ & 0.022 & 1 & 0.022 & 386.81 & $<0.0001$ & $* *$ \\
\hline Residual & 0.000395 & 7 & 0.00005643 & & & \\
\hline Lack of fit & 0.000275 & 3 & 0.00009167 & 3.06 & 0.1544 & Not significant \\
\hline Pure error & 0.00012 & 4 & 0.00003 & & & \\
\hline Cor total & 0.15 & 16 & & & & \\
\hline$R^{2}$ & 0.9974 & & & & & \\
\hline Adj $R^{2}$ & 0.9941 & & & & & \\
\hline Pred $R^{2}$ & 0.9699 & & & & & \\
\hline Adeq precision & 76.154 & & & & & \\
\hline CV\% & 0.69 & & & & & \\
\hline
\end{tabular}

${ }^{* *} p \leq 0.01$

USA). The relative levels of target proteins were determined based on the optical density of the electrophoresis bands, with $\beta$-actin serving as an internal control.

2.10. Statistical Analysis. Experiment values are means of three replicate samples $(n=3)$. All experiment results were expressed as means \pm standard deviation. The RSM experiment data were analyzed by Design Expert 8.0.6 software, and other experiment data were analyzed statistically by SPSS 17.0 (SPSS 17.0 for Windows; SPSS Inc., Chicago, IL). In all statistical analyses, $p$ values $\leq 0.05$ were regarded as statistically significant and $p$ values $\leq 0.01$ as very significance.

\section{Results and Discussion}

\subsection{Optimize Extraction Conditions for Total Flavonoids}

\subsubsection{Experimental Design}

(1) Single Factor Experiments. According to related literature [42-44] and preliminary single-factor and response surface experiments, three major influence factors, namely, the extraction time $(A, \mathrm{~min})$, concentration of ethanol solution $(B, \%)$, and ratio of solvent to material $(C, \mathrm{ml} / \mathrm{g})$, were investigated for optimum extraction, and the yields of the flavonoid fraction from $A$. theophrasti leaves were determined using an inspection index. The flavonoid fractions were prepared on the basis of the following factors: concentration of ethanol solution $(20 \%, 40 \%, 60 \%, 80 \%$, and $100 \%)$, extraction time $(10,15,20,25$, and $30 \mathrm{~min})$, and ratio of solvent to material $(10: 1,15: 1,20: 1,25: 1$, and $30: 1 \mathrm{ml} / \mathrm{g})$ in two extraction cycles. As one influence factor was evaluated, the middle levels were chosen for the other two factors. The filtrate was concentrated to $10 \mathrm{ml}$ prior to the measurement of TFC.

(2) Optimization of Extraction Conditions by a BoxBehnken Design. On the basis of the single-factor experiments, three levels were confirmed for the three factors, and then, a Box-Behnken design (BBD) of three variables ( $A$, extraction time; $B$, concentration of ethanol solution; and $C$, ratio of solvent to material) and three levels (Design-Expert software, Trial Version 8.0.6, State Inc., Minneapolis, USA) was introduced to optimize the extraction procedure of the flavonoid fraction from $A$. theophrasti leaves. The independent variables and the ranges of their levels are listed in Table 2, and the yield of the flavonoid fraction was considered the dependent variable. As shown in Table 3, the BBD consisted of twelve factorial points and five replicates of central points in the response surface experiment, and the experimental runs were randomized to minimize the effects of unpredictable variability in the observed responses.

\subsubsection{Optimization of Extraction Conditions by $B B D$}

(1) Model Fitting and Statistical Analysis. As shown in the design matrix (Table 3), 17 experiments were performed with the yield of the flavonoid fraction from $A$. theophrasti leaves as an index. The data were analyzed statistically by multiple regression analysis using Design Expert software (version 


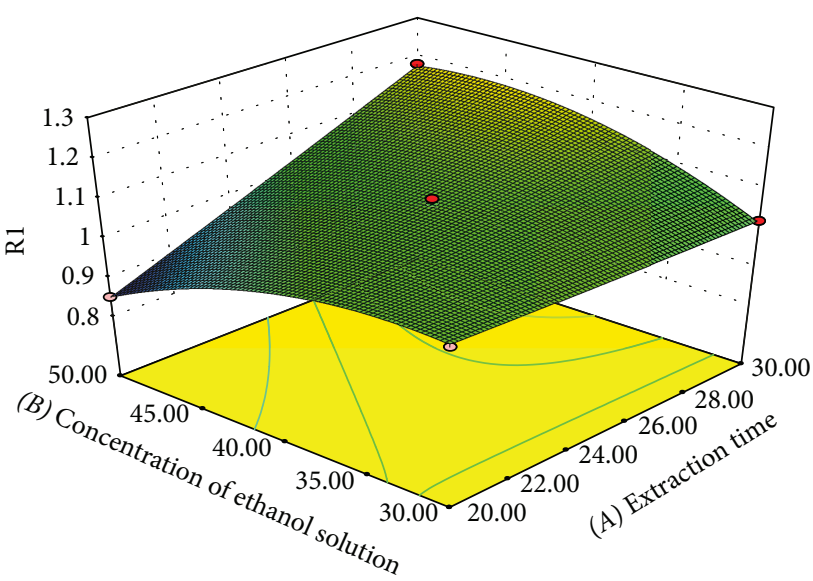

(a)

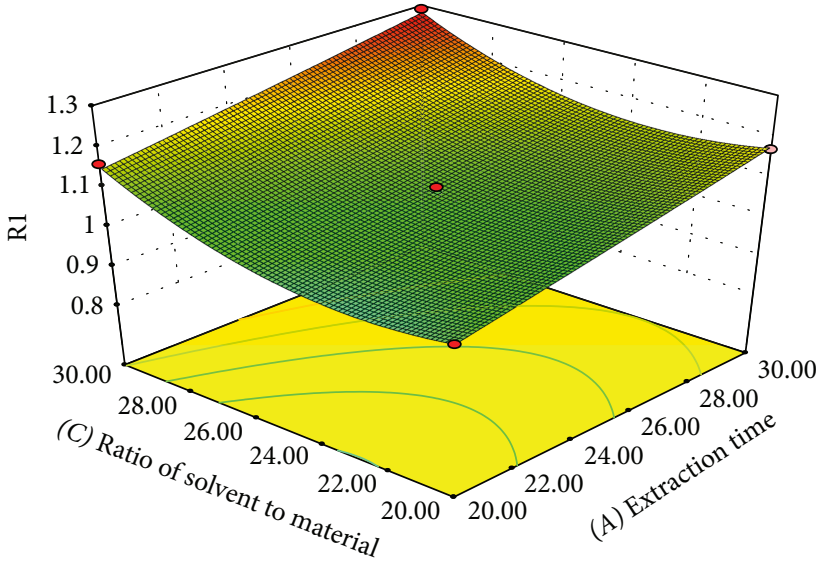

(b)

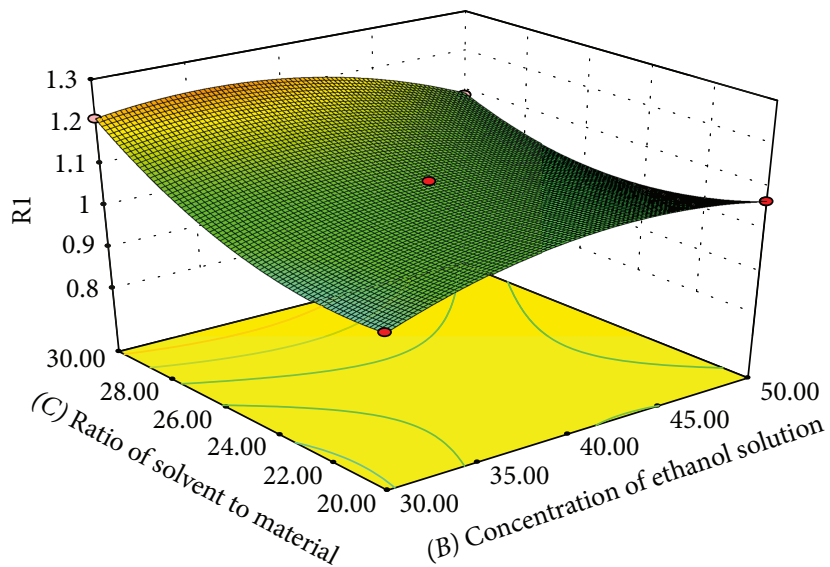

(c)

Figure 1: (a-c) Response surface plots showing the effect of extraction time ( $A$, min), concentration of ethanol solution $(B, \%)$ and ratio of solvent to material $(C, \mathrm{ml} / \mathrm{g})$ on TFE yield.

TABLE 5: TFC (\%) and $\mathrm{IC}_{50}$ values for evaluating antioxidant assays and $\mathrm{EC}_{50}$ values for reducing power of TFE from $A$. theophrasti leaves.

\begin{tabular}{lcccc}
\hline Number & $\begin{array}{c}\mathrm{TFC} \\
(\%)\end{array}$ & $\begin{array}{c}\mathrm{IC}_{50 \mathrm{ABTS}} \\
(\mu \mathrm{g} / \mathrm{ml})\end{array}$ & $\begin{array}{c}\mathrm{IC}_{50 \mathrm{DPPH}} \\
(\mu \mathrm{g} / \mathrm{ml})\end{array}$ & $\begin{array}{c}\mathrm{EC}_{50 \mathrm{FRAP}} \\
\left(\mathrm{mmol} \mathrm{Fe}^{2+} /\right. \\
0.1 \mu \mathrm{g} / \mathrm{ml})\end{array}$ \\
\hline Aug. sample & $1.29 \pm 0.02$ & 3.10 & 8.96 & 0.33 \\
Sep. sample & $1.31 \pm 0.01$ & 2.95 & 8.41 & 0.41 \\
Oct. sample & $0.83 \pm 0.02$ & 5.31 & 14.41 & 0.23 \\
BHT & - & 2.25 & 8.11 & 0.14 \\
\hline
\end{tabular}

$\mathrm{IC}_{50}$ : inhibition concentration $50 \%$.

8.0.6) to obtain the following flavonoid fraction final equation in terms of coded factors:

$$
\begin{aligned}
Y= & 1.09+0.074 A-0.01 B+0.061 C+0.088 A B-0.005 A C \\
& -0.047 B C+0.002 A^{2}-0.066 B^{2}+0.072 C^{2} .
\end{aligned}
$$

According to the calculated coefficient $\left(R^{2}=0.9974\right)$ obtained by ANOVA of the quadratic regression model

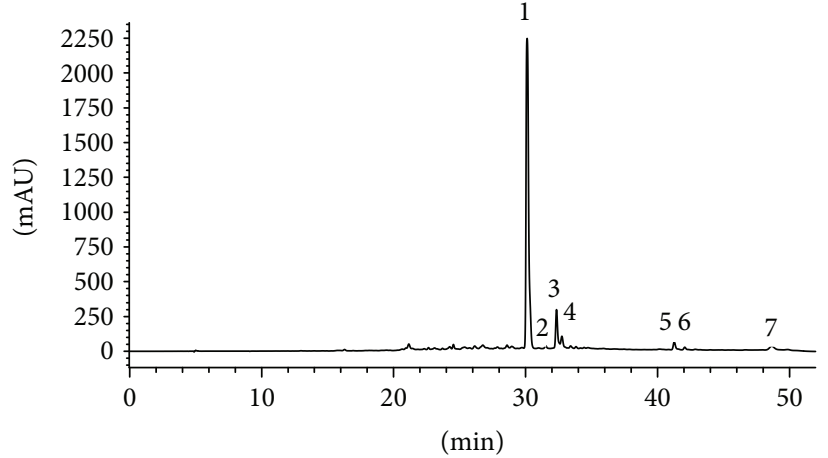

FIgURE 2: Chromatographic profile at $350 \mathrm{~nm}$ of TFE of $A$. theophrasti leaves.

(Table 4 ), only $0.26 \%$ of total variance cannot be explained by the model, and the adjusted $R^{2}$ at 0.9941 demonstrated a better correlation between the experimental values and predicted values. In addition, the lower $p$ value $(p \leq 0.0001)$ suggested that the model significantly represents the true relationship between the parameters and the response. Furthermore, a lower coefficient of variation $(\mathrm{CV})$ of 0.69 
TABLE 6: The major compounds in TFE identified by HPLC-DAD-ESI-MS ${ }^{\mathrm{n}}$ analysis.

\begin{tabular}{|c|c|c|c|c|c|c|c|c|c|}
\hline Peak & Rt & {$[\mathrm{M}-\mathrm{H}]^{-}$} & $\begin{array}{c}\mathrm{MS} / \mathrm{MS} \\
{[\mathrm{M}-\mathrm{H}]^{-}}\end{array}$ & {$[\mathrm{M}+\mathrm{H}]^{+}$} & $\begin{array}{c}\mathrm{MS} / \mathrm{MS} \\
{[\mathrm{M}+\mathrm{H}]^{+}}\end{array}$ & $\begin{array}{l}\text { Calculated } \\
\text { mass }\end{array}$ & Formula & Proposed molecule & References $^{\mathrm{b}}$ \\
\hline $1^{\mathrm{a}}$ & 30.1 & 609 & 463,301 & 611 & 465,303 & 610 & $\mathrm{C}_{27} \mathrm{H}_{30} \mathrm{O}_{16}$ & Rutin & {$[24]$} \\
\hline 2 & 31.5 & 463 & 301 & 465 & 303 & 464 & $\mathrm{C}_{21} \mathrm{H}_{20} \mathrm{O}_{12}$ & Quercetin-7-O- $\beta$-glucoside & {$[49]$} \\
\hline 3 & 32.3 & 593 & 447,285 & 595 & 449,287 & 594 & $\mathrm{C}_{27} \mathrm{H}_{30} \mathrm{O}_{15}$ & $\begin{array}{c}\text { Kaempferol 3-O- } \alpha \text { - } \\
\text { rhamnopyranosyl }(1 \rightarrow 6) \text { - } \\
\beta \text {-glucopyranoside }\end{array}$ & [49] \\
\hline 4 & 32.5 & 285 & - & 287 & - & 286 & $\mathrm{C}_{15} \mathrm{H}_{10} \mathrm{O}_{6}$ & Luteolin & {$[24]$} \\
\hline 5 & 41.3 & 593 & 447,285 & 595 & 449,287 & 594 & $\mathrm{C}_{27} \mathrm{H}_{30} \mathrm{O}_{15}$ & Apigenin-7-O- $\beta$-diglucoside & {$[46]$} \\
\hline 6 & 42.1 & 593 & 447,285 & 595 & 449,287 & 594 & $\mathrm{C}_{27} \mathrm{H}_{30} \mathrm{O}_{15}$ & Poncirin & [47] \\
\hline 7 & 48.7 & 593 & 447,285 & 595 & 449,287 & 594 & $\mathrm{C}_{27} \mathrm{H}_{30} \mathrm{O}_{15}$ & Tiliroside & [48] \\
\hline
\end{tabular}

${ }^{\mathrm{a}}$ Peak number as in Figure 2. ${ }^{\mathrm{b}}$ The reference column refers to previous reports on metabolites in different plants.

indicates the better precision, accuracy, reliability, and reproducibility of the model.

ANOVA was applied to evaluate the significance of the regression coefficients of the response surface quadratic regression model. As shown in Table 4, the linear coefficients and quadratic term coefficients of the extraction time $(A)$, concentration of ethanol solution $(B)$, and ratio of solvent to material $(C)$ were all very significant $(p \leq 0.01)$. Furthermore, there were very significant differences $(p \leq 0.01)$ in the interactions between $A$ and $B$ and between $B$ and $C$, while no significant linear and quadratic effect was observed between $A$ and $C(p>0.05)$. In addition, $B^{2}$ and $C^{2}$ had a very significant $(p \leq 0.01)$ influence on the yield of the flavonoid fraction, which indicated that the influence factors did not have a simple linear or quadratic relationship (Table 4).

(2) Graphical Interpretation and Optimization of Procedure. The relationship between the response and the experimental level for each of the three factors was visualized by the surface and contour plots on the basis of the derived equations, and the optimum conditions for the maximum yield of TFE could be deduced.

As shown in Figure 1, the extraction yield of TFE from $A$. theophrasti leaves can also be predicted by the threedimensional (3D) response surface and two-dimensional (2D) contour plots of extraction time $(A)$, concentration of ethanol solution $(B)$, and ratio of solvent to material $(C)$, which influence the yield of TFE to with different degrees.

Figure 1(a) shows that the interaction between the extraction time $(A)$ and concentration of ethanol solution $(B)$ had a very significant influence $(p \leq 0.01)$ on the yield of TFE when the ratio of solvent to material $(C)$ was kept at a middle level. The experimental results demonstrated that the yield of TFE increased when the extraction time was increased from 20 to $30 \mathrm{~min}$. However, compared to the growth rate increase from 20 to $25 \mathrm{~min}$, the extraction yield increased slowly from 25 to $30 \mathrm{~min}$. In consideration of the time, cost, and test index, $30 \mathrm{~min}$ was set as the longest extraction time.

The extraction time $(A)$ and the ratio of solvent to material $(C)$ had minor effects on the TFE yield (Figure 1(b)). The extraction yield increased with changes in the extraction time (A) from 20 to $30 \mathrm{~min}$ and in the ratio of solvent to material from 20 to $30 \mathrm{ml} / \mathrm{g}$. However, the interaction effect for the
TABLE 7: Correlation coefficients between assays.

\begin{tabular}{lcccc}
\hline & ABTS & DPPH & FRAP & TFC (\%) \\
\hline ABTS & 1 & $1.000^{*}$ & -0.920 & $-1.000^{*}$ \\
DPPH & - & 1 & -0.930 & $-0.999^{*}$ \\
FRAP & - & - & 1 & 0.912 \\
TFC $(\%)$ & - & - & - & 1 \\
\hline
\end{tabular}

${ }^{*}$ Significant at $p \leq 0.05$.

yield of TFE relative to the extraction time and to the ratio of solvent to material was not significant $(p>0.05)$.

The extraction yield gradually increased with increasing concentrations of ethanol solution reaching a maximum at $42.8 \%$ and finally declined within the range of 42.8 to $50 \%$ (Figure 1(c)). However, the yield was positively correlated with the increasing ratio of solvent to material from 20 to $30 \mathrm{ml} / \mathrm{g}$. The mutual interaction between the ethanol concentration and the ratio of solvent to material was very significant $(p \leq 0.01)$. The above results were in accordance with the ANOVA test.

(3) Optimization of Extraction Parameters. Because of the optimum extraction conditions that were visually observed, the extraction processing parameters were optimized by a response surface methodology instead of by the orthogonal test (60\% ethanol solution, ratio of solvent to material $30: 1$ $(\mathrm{ml} / \mathrm{g})$, and extraction time $20 \mathrm{~min}$ ) that was published previously [45]. The processing parameters were optimized by Design-Expert software as follows: extraction time $30 \mathrm{~min}$; concentration of ethanol solution $42.28 \%$; and ratio of solvent to material 30:1. For operational convenience, the concentration of ethanol solution was adjusted to $42.3 \%$. The experiments were performed in triplicate under the revised conditions, and the yield $(1.31 \pm 0.01 \%)$ was only slightly higher than the predicted result (1.29\%), indicating a good correspondence between the experimental and predicated values.

3.1.3. TFC of A. theophrasti Leaves. The flavonoid fraction from $A$. theophrasti leaves was extracted by conditions that were optimized with model equations, and the yields of the flavonoid fractions were $1.29 \pm 0.02 \%, 1.31 \pm 0.01 \%$, and 
TABLE 8: MIC values of TFE from $A$. theophrasti leaves against pathogenic bacteria (mean $\pm \mathrm{SD} ; n=3$ ).

\begin{tabular}{lcccc}
\hline Sample & $\begin{array}{c}\text { Escherichia coli } \\
\text { (ATCC 25922) }\end{array}$ & $\begin{array}{c}\text { Salmonella } \\
\text { (ATCC 51812) }\end{array}$ & $\begin{array}{c}\text { Staphylococcus aureus } \\
\text { (ATCC 25923) }\end{array}$ & $\begin{array}{c}\text { Streptococcus } \\
\text { (ATCC 49619) }\end{array}$ \\
\hline Gentamicin $(\mu \mathrm{g} / \mathrm{ml})$ & $2.00 \pm 0.02$ & $0.50 \pm 0.01$ & $0.50 \pm 0.01$ & $1.00 \pm 0.01$ \\
TFE $(\mathrm{g}$ crude drug/ml) & $1.02 \pm 0.04$ & $0.51 \pm 0.02$ & $0.06 \pm 0.01$ & $0.26 \pm 0.01$ \\
\hline
\end{tabular}

$0.83 \pm 0.02 \%$ for the samples collected in August, September, and October 2014, respectively (Table 5). The results indicated that there was a clear correlation between TFC and the month in which the medicinal materials were harvested. The order of TFC from A. theophrasti leaves in different harvest months was as follows: September $>$ August $>$ October. This finding suggests that TFC might be related to the external environment and internal physiological factors. Therefore, it is necessary to choose an appropriate time for collecting medicinal materials to be used for research on the pharmacological action and content of active components of TFC.

3.2. Chemical Component Analysis of TFE. The chemical components present in TFE were identified and analyzed by HPLC-DAD-ESI-MS ${ }^{\mathrm{n}}$ in positive and negative ion modes. The UV chromatogram was recorded at $350 \mathrm{~nm}$ (Figure 2) and exhibited peaks of multiple heights. The mass and MS/ MS fragmentation patterns obtained from the electrospray mass spectra are shown in Table 6. Using this procedure, rutin, quercetin $7-O-\beta$-glucoside, kaempferol 3-O- $\alpha$-rhamnopyranosyl $(1 \rightarrow 6)$ - $\beta$-glucopyranoside, luteolin, apigenin 7-O- $\beta$-diglucoside, poncirin, and tiliroside were characterized tentatively according to the literature [24, 46-49]. This research will provide a foundation for the study of the quality control methods and pharmacological effects of TFE from A. theophrasti leaves.

3.3. Antioxidant Activity Analysis. As described in Table 5, the highest antioxidant activity was measured in the Sep. sample, which had the lowest $\mathrm{IC}_{50}$ ABTS $(2.95 \mu \mathrm{g} / \mathrm{ml})$ and $\mathrm{IC}_{50 \mathrm{DPPH}}(8.41 \mu \mathrm{g} / \mathrm{ml})$ and the highest $\mathrm{EC}_{50 \text { FRAP }}(0.41 \mathrm{mmol}$ $\mathrm{Fe}^{2+} / 0.1 \mu \mathrm{g} / \mathrm{ml}$ ); followed by the Aug. sample, with $\mathrm{IC}_{50}$ $\mathrm{ABTS}=3.10 \mu \mathrm{g} / \mathrm{ml}, \quad \mathrm{IC}_{50} \quad \mathrm{DPPH}=8.96 \mu \mathrm{g} / \mathrm{ml}$, and $\mathrm{EC}_{50}$ FRAP $=0.33 \mathrm{mmol} \mathrm{Fe} e^{2+} / 0.1 \mu \mathrm{g} / \mathrm{ml}$; and finally Oct. sample, with $\mathrm{IC}_{50} \quad \mathrm{ABTS}=5.31 \mu \mathrm{g} / \mathrm{ml}, \quad \mathrm{IC}_{50} \mathrm{DPPH}=14.41 \mu \mathrm{g} / \mathrm{ml}$, and $\mathrm{EC}_{50}$ FRAP $=0.23 \mathrm{mmol} \mathrm{Fe}{ }^{2+} / 0.1 \mu \mathrm{g} / \mathrm{ml}$. Compared to the BHT positive control, with $\mathrm{IC}_{50}$ ABTS $2.25 \mu \mathrm{g} / \mathrm{ml}, \mathrm{IC}_{50 \mathrm{DPPH}} 8.11 \mu \mathrm{g} / \mathrm{ml}$, and $\mathrm{EC}_{50}$ FRAP $0.14 \mathrm{mmol} \mathrm{Fe}{ }^{2+} / 0.1 \mu \mathrm{g} / \mathrm{ml}$, the Sep. sample displayed much higher FRAP and nearly identical scavenging abilities for DPPH and ABTS free radicals. Furthermore, the FRAPs of the Aug. and Oct. samples were approximately 2.4-fold and 1.7-fold stronger than BHT, respectively.

The three antioxidant assays suggested that the antioxidant activities of TFE correlated with the months during which A. theophrasti leaves were collected. Because of their reducing power, all three samples can replace synthetic antioxidant BHT in the pharmaceutical and food industries. In view of the scavenging abilities of the DPPH and ABTS free radicals, the antioxidant activities of the Aug. and Sep. samples were

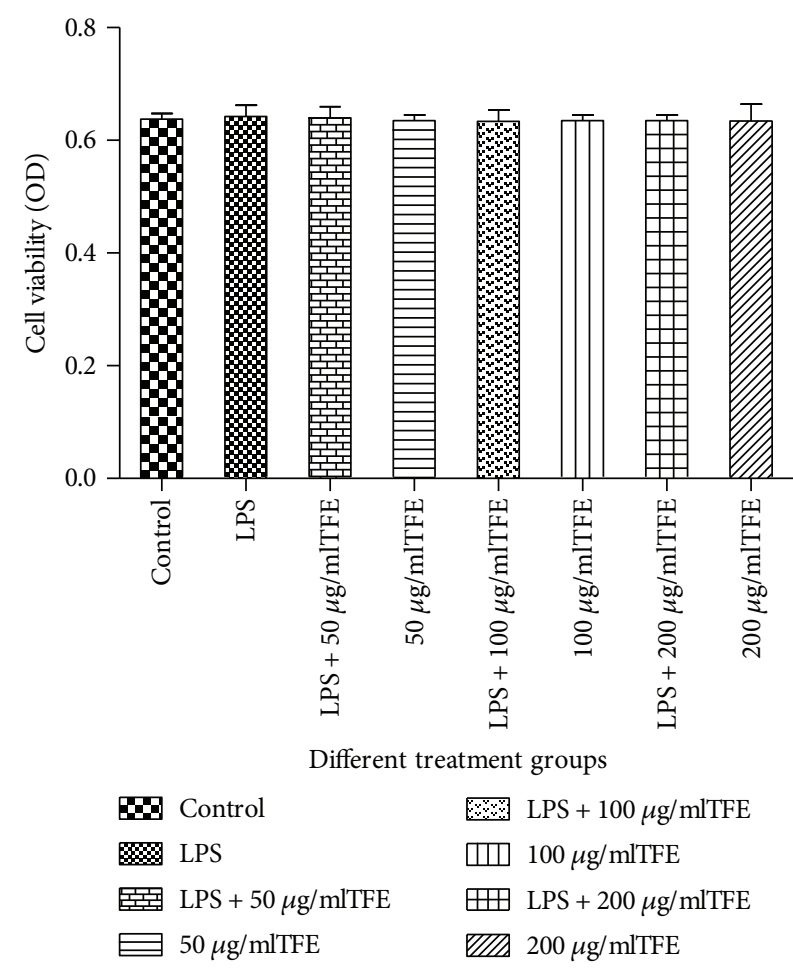

FIgURE 3: Effect of TFE on the viability of RAW 264.7 cells. Cells were cultured with TFE $(50,100$, and $200 \mu \mathrm{g} / \mathrm{ml})$ in the absence or presence of $1 \mu \mathrm{g} / \mathrm{ml}$ LPS for $18 \mathrm{~h}$; then, cell viability was measured by MTT assay. Data are presented as means \pm SD of three independent experiments.

higher than those of the Oct. sample. Therefore, they are likely to be able to substitute for synthetic antioxidants. Therefore, $A$. theophrasti leaves should be a good candidate for the research and development of healthy and natural antioxidants in the food and pharmaceutical industries.

3.4. Pearson Correlation Analysis between TFC and Antioxidant Activity. In this research, the antioxidant activities of TFE were investigated using assays of ABTS radical scavenging activity, DPPH radical scavenging activity, and FRAP. To further understand the interrelationships between the antioxidant activity and TFC, the Pearson test was used to analyze the interaction between the two factors, and the results of the correlations among the parameters are shown in Table 7. The correlations were significant $(p \leq 0.05)$ between TFC and the antioxidant activity measured by the ABTS assay $(r,-1.000)$ and between TFC and the results of 


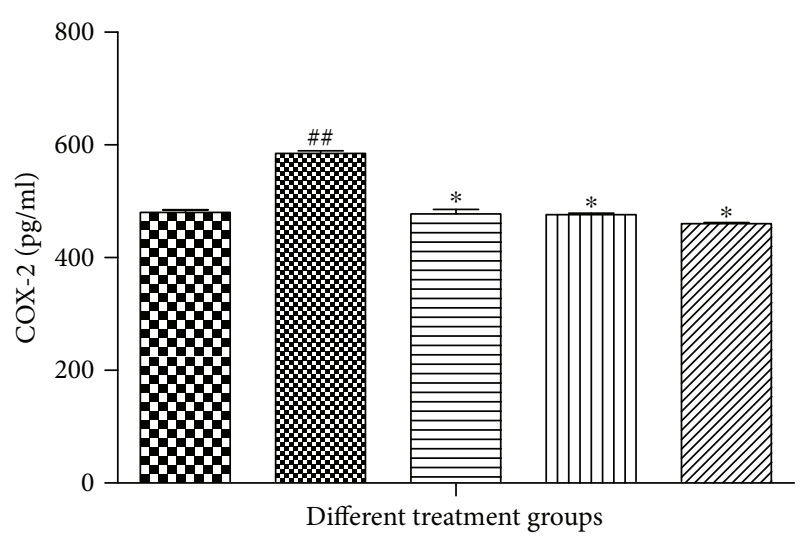

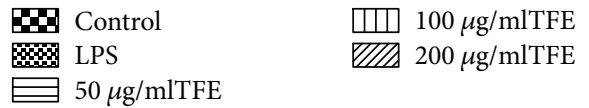

(a)

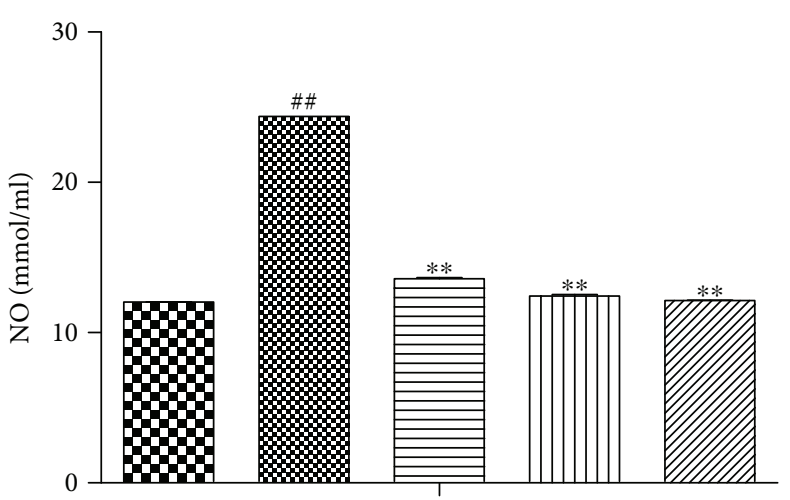

Different treatment groups

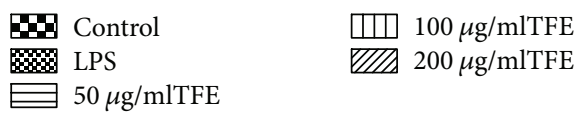

(b)

FIGURE 4: Effects of different concentrations of TFE on LPS induced COX-2 (a) and NO (b) production in RAW 264.7 cells. Cells were pretreated with TFE $(50,100$, and $200 \mu \mathrm{g} / \mathrm{ml})$ for $1 \mathrm{~h}$, followed by LPS $(1 \mu \mathrm{g} / \mathrm{ml})$ stimulation for $18 \mathrm{~h}$. Values represent the mean \pm SD of the three independent experiments $\left({ }^{\# \#}\right.$ compared with the control, ${ }^{*}$ compared with LPS; ${ }^{*} p \leq 0.05$ and $\left.{ }^{* * / \# \#} p \leq 0.01\right)$.

the DPPH assay $(r,-0.999)$. Furthermore, there was a better correlation $(r, 0.912)$ between TFC and the values of the FRAP assay, although the correlation was not significant $(p>0.05)$. These results indicated that TFC contributes to the antioxidant activity and that the correlation is higher between the antioxidant activity and TFC.

Table 7 also shows the results of correlations between the three methods used to evaluate the antioxidant activity of TFE. A significant correlation $(p \leq 0.05)$ was found between the DPPH and ABTS assays $(r, 1.000)$. Moreover, better correlations were found between FRAP and ABTS and FRAP and $\mathrm{DPPH}$, with $r$ values of -0.920 and -0.930 , respectively. This implies that the correlations were much better for the three quantification methods of antioxidation activity of TFE, and the results were consistent with those of the three antioxidant assays.

3.5. Antimicrobial Activity Analysis. The antibacterial activities of TFE from $A$. theophrasti leaves against four bacteria strains are shown in Table 8. Gentamicin, as a standard antibiotic, was used as a positive control to ensure the accuracy and reliability of the assay method for antibacterial activity. As shown in Table 8, the order of the inhibitory effect of TFE on the four bacteria was as follows: first, Staphylococcus aureus, with an MIC value of $0.06 \pm 0.01 \mathrm{~g}$ crude drug $/ \mathrm{ml}$; second, Streptococcus, with an MIC value of $0.26 \pm 0.01 \mathrm{~g}$ crude drug/ml; third, Salmonella, with an MIC value of $0.51 \pm 0.02 \mathrm{~g}$ crude drug $/ \mathrm{ml}$; and finally, Escherichia coli, with an MIC value of $1.02 \pm 0.04 \mathrm{~g}$ crude drug $/ \mathrm{ml}$. These results suggested that the inhibitory effect of TFE on the four bacteria is greater than that of gentamicin. In addition, the inhibitory effect of TFE was stronger on the gram-positive bacteria than on the gram-negative bacteria. This study confirmed that TFE exhibits potential antibacterial activity and provides a foundation for research on replacing or decreasing antibiotic applications in the clinic.
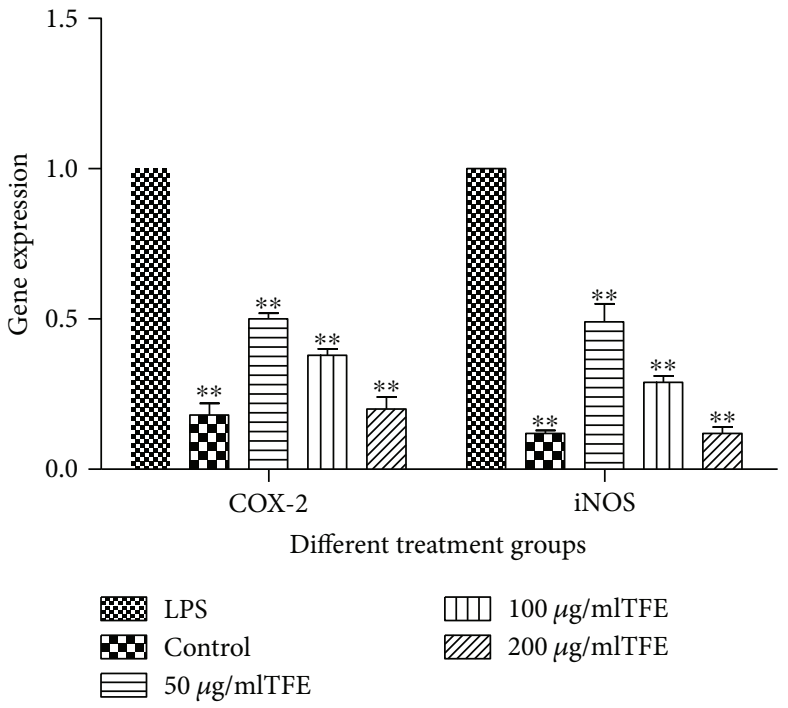

FIGURE 5: Effects of different concentrations of TFE on LPS induced COX-2 and iNOS genes expression in RAW 264.7 cells. Cells were pretreated with TFE $(50,100$, and $200 \mu \mathrm{g} / \mathrm{ml})$ for $1 \mathrm{~h}$, followed by LPS $(1 \mu \mathrm{g} / \mathrm{ml})$ stimulation for $18 \mathrm{~h}$. Values represent the mean \pm SD of the three independent experiments $\left({ }^{* *}\right.$ compared with LPS; **/\#\# $p \leq 0.01)$.

\subsection{Anti-Inflammatory Activity Analysis}

3.6.1. Effect of TFE on the Cell Viability. The inhibitory effect of TFE on RAW 264.7 cell growth was evaluated by the MTT assay. Cells were incubated with TFE at concentrations of 50, 100 , and $200 \mu \mathrm{g} / \mathrm{ml}$ after being pretreated with LPS or medium only. The results showed that cell viabilities (99.3-100.7\%) were not significantly $(p>0.05)$ affected by TFE in the experimental concentration range (Figure 3 ).

3.6.2. Effect of TFE on the Content of COX-2 and NO and on the Genes Expression Levels of COX-2 and iNOS. Previous 


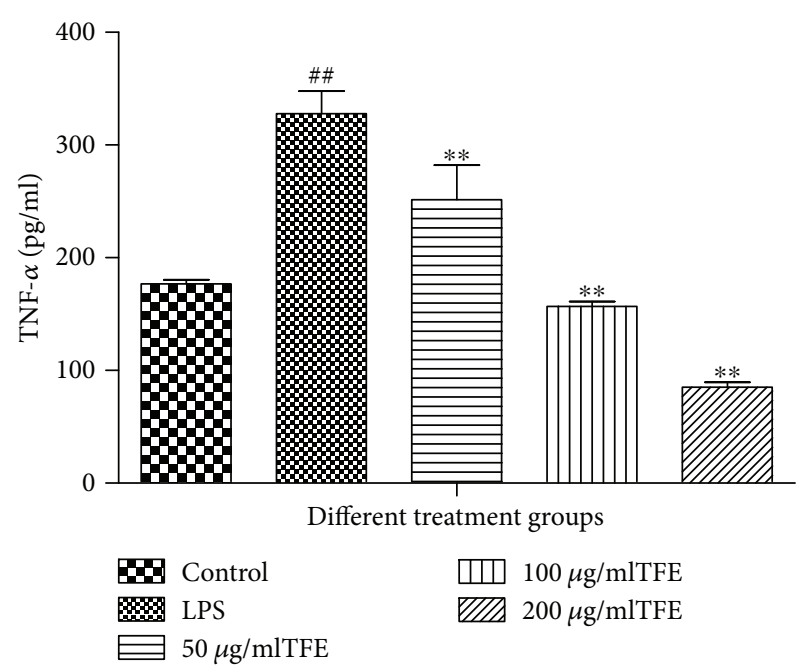

(a)
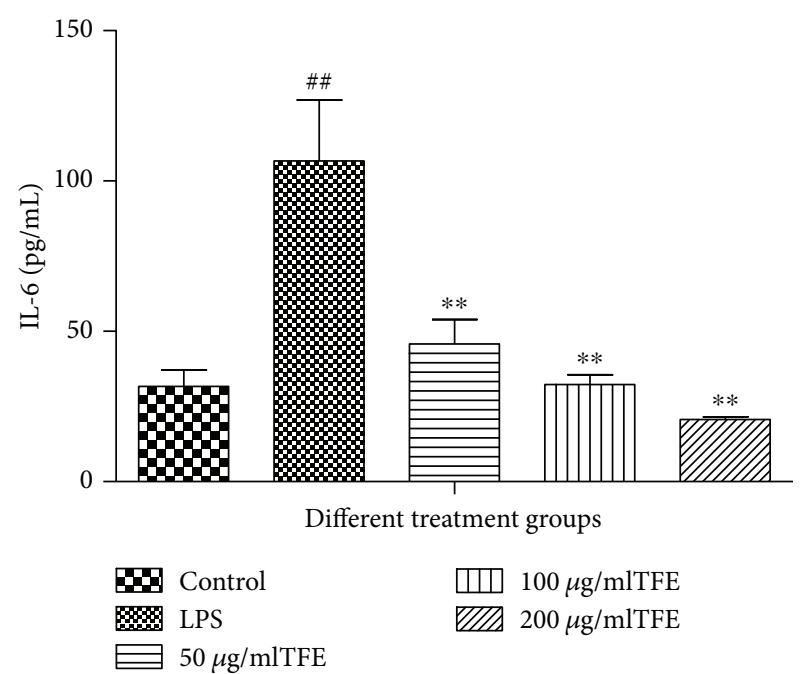

(c)

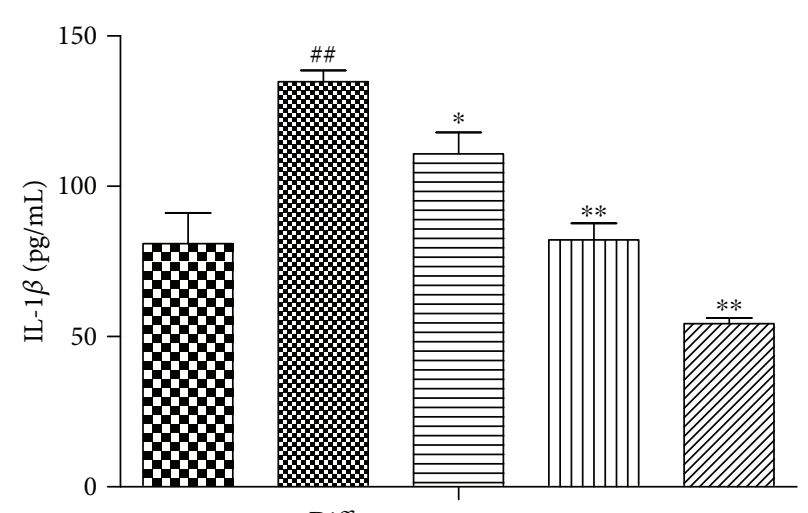

Different treatment groups

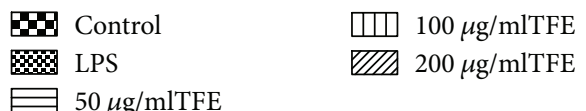

(b)
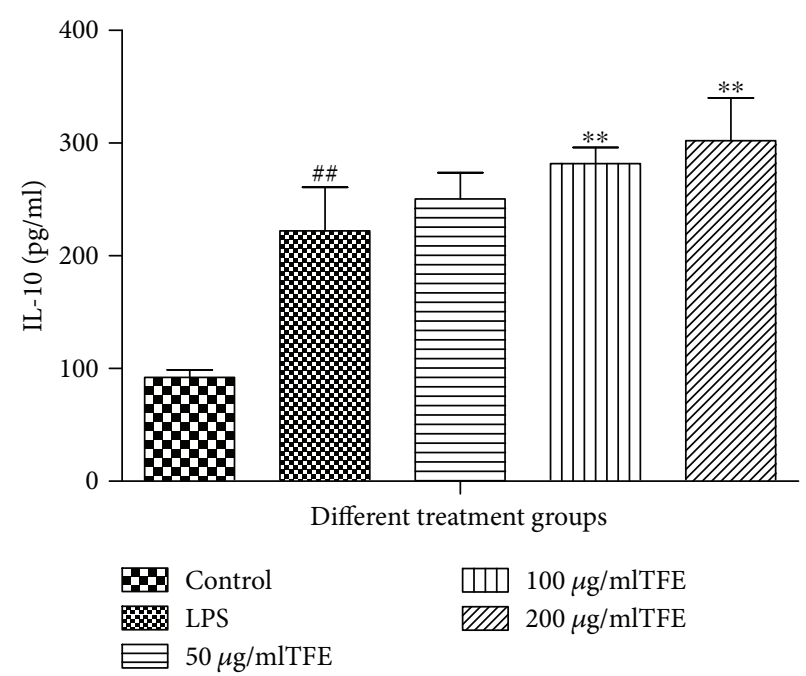

(d)

FIGURE 6: Effect of different concentrations of TFE on secretion of TNF- $\alpha$ (a), IL-1 $\beta$ (b), IL-6 (c), and IL-10 (d) in vitro. The cells were treated with LPS alone or LPS plus different concentrations $(50,100$, and $200 \mu \mathrm{g} / \mathrm{ml}$ ) of TFE for $18 \mathrm{~h}$. The values represent means \pm SD of the three independent experiments $\left({ }^{\# \#}\right.$ compared with the control, ${ }^{*}$ compared with LPS; ${ }^{*} p \leq 0.05$ and $\left.{ }^{* * / \# \#} p \leq 0.01\right)$.

studies indicated that baicalein can inhibit COX-2 gene expression in LPS-induced RAW 264.7 cells. Moreover, wogonin and quercetin suppressed $\mathrm{NO}$ production in a dose-dependent manner in the same model. In addition, rutin $(80 \mu \mathrm{M})$ clearly displayed an inhibitory effect on NO production induced by LPS in primary peritoneal macrophages $[50,51]$. Furthermore, wogonin significantly inhibited NO production by suppressing iNOS mRNA and protein expression levels [52].

To investigate the anti-inflammatory activities and molecular mechanisms of TFE from $A$. theophrasti leaves, we first examined the ability of TFE to regulate the production of COX-2 and $\mathrm{NO}$ and their gene expression levels in response to LPS stimulation. According to the results shown in Figure 4, the concentrations of COX-2 and NO increased very significantly $(p \leq 0.01)$ in the LPS group compared to the control group, and compared with the LPS group, their concentrations significantly decreased in a dose-dependent manner in the experimental groups pretreated with 50,100, and $200 \mu \mathrm{g} / \mathrm{ml}$ of TFE.

Based on the inhibitory effect of TFE against the production of COX-2 and NO induced by LPS, the regulation of their gene expression was examined in TFE-treated RAW 264.7 cells. As shown in Figure 5, the expression levels of COX-2 and iNOS genes were significantly $(p \leq 0.01)$ decreased in a concentration-dependent manner in the groups treated with 50,100, and $200 \mu \mathrm{g} / \mathrm{ml}$ of TFE compared with the LPS-treated group. These studies indicated that TFE has a direct inhibitory effect on the production of COX-2 and $\mathrm{NO}$ and blocks their gene expression in LPS-induced RAW 264.7 cells. The results are consistent with those reported in the literature.

3.6.3. Effect of TFE on the Cytokine Secretion. In a study by Abdallah et al. [53], the anti-inflammatory activities of amentoflavone, apigenin-7-O- $\beta$-D-glucopyranoside, acacetin-7- 


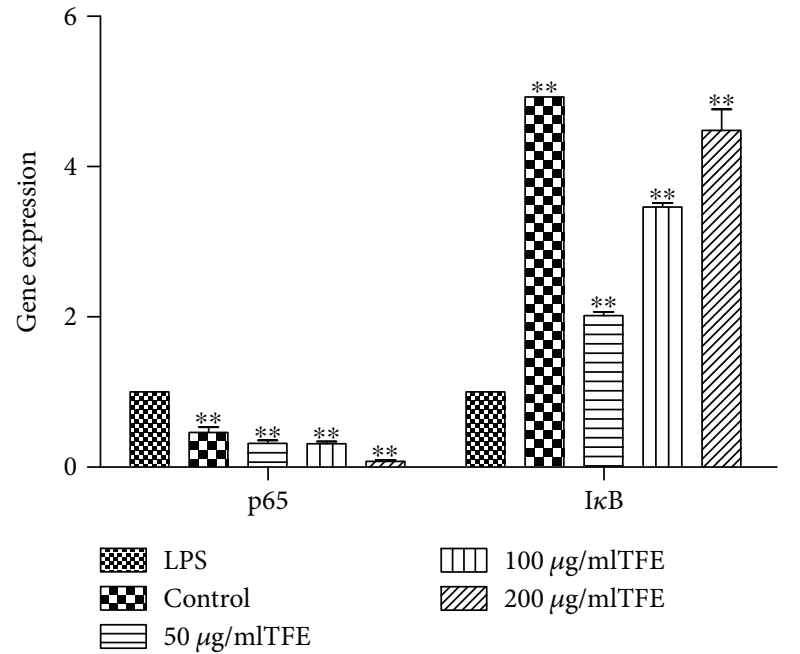

FIgURE 7: Effects of different concentrations of TFE on the genes expression of $\mathrm{p} 65$ and $\mathrm{I} \kappa \mathrm{B}$ in NF- $\kappa \mathrm{B}$ signaling pathway in LPS induced RAW 264.7 cells. Cells were pretreated with TFE $(50,100$, and $200 \mu \mathrm{g} / \mathrm{ml})$ for $1 \mathrm{~h}$, followed by LPS $(1 \mu \mathrm{g} / \mathrm{ml})$ stimulation for $18 \mathrm{~h}$. Values represent the mean \pm SD of the three independent

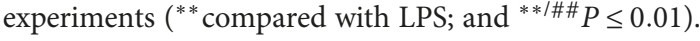

$O-\beta$-D- $[\alpha$-L-rhamnosyl $(1 \rightarrow 6)] 3^{\prime \prime}$-E- $p$-coumaroyl glucopyranoside and rutin were assessed by measuring the levels of IL- $1 \beta$, IL- 6 , and TNF- $\alpha$ in the supernatant media of human peripheral blood mononuclear cells (PBMCs) stimulated by phytohemagglutinin. The four isolated flavonoid compounds decreased the content of IL- $1 \beta$, IL- 6 , and TNF- $\alpha$ significantly at a concentration of $100 \mu \mathrm{M}$ [53].

Moreover, Nakamura et al. [54] reported that the production and mRNA expression levels of IL- 6 and IL- 8 were significantly suppressed by baicalein and wogonin in a study of the effects of baicalin, baicalein, and wogonin on the protein and mRNA expression levels of IL- 6 and IL- 8 and on NF- $\kappa$ B binding activities induced by IL- $1 \beta$ in a human retinal pigment epithelial cell line cells.

In the present study, 50, 100, and $200 \mu \mathrm{g} / \mathrm{ml}$ of TFE reduced $(p \leq 0.01)$ the content of IL- $1 \beta$, IL- 6 , and TNF- $\alpha$ and enhanced $(p \leq 0.05)$ the concentration of IL-10 compared to the LPS-treated group (Figure 6). The research suggested that TFE from $A$. theophrasti leaves can suppress the inflammatory response directly by decreasing the production of proinflammatory cytokines and by increasing the content of suppression inflammatory cytokines. The results are consistent with the above literatures.

3.6.4. Effect of TFE on LPS-Induced NF- $\kappa B$ Signaling Pathways Activation. NF- $\kappa \mathrm{B}$ signaling pathways are important for regulation of the synthesis and secretion of cytokines and mediators of the inflammatory response $[55,56]$. To evaluate whether NF- $\kappa \mathrm{B}$ signaling pathways are related to the anti-inflammatory activity of TFE from $A$. theophrasti leaves, RAW 264.7 cells were pretreated with 50, 100, and $200 \mu \mathrm{g} / \mathrm{ml}$ of TFE for $1 \mathrm{~h}$ followed by LPS $(1 \mu \mathrm{g} / \mathrm{ml})$ stimulation for $18 \mathrm{~h}$. The levels of expression of $p 65$ and $I \kappa B$ genes were determined by real-time fluorescence quantitative

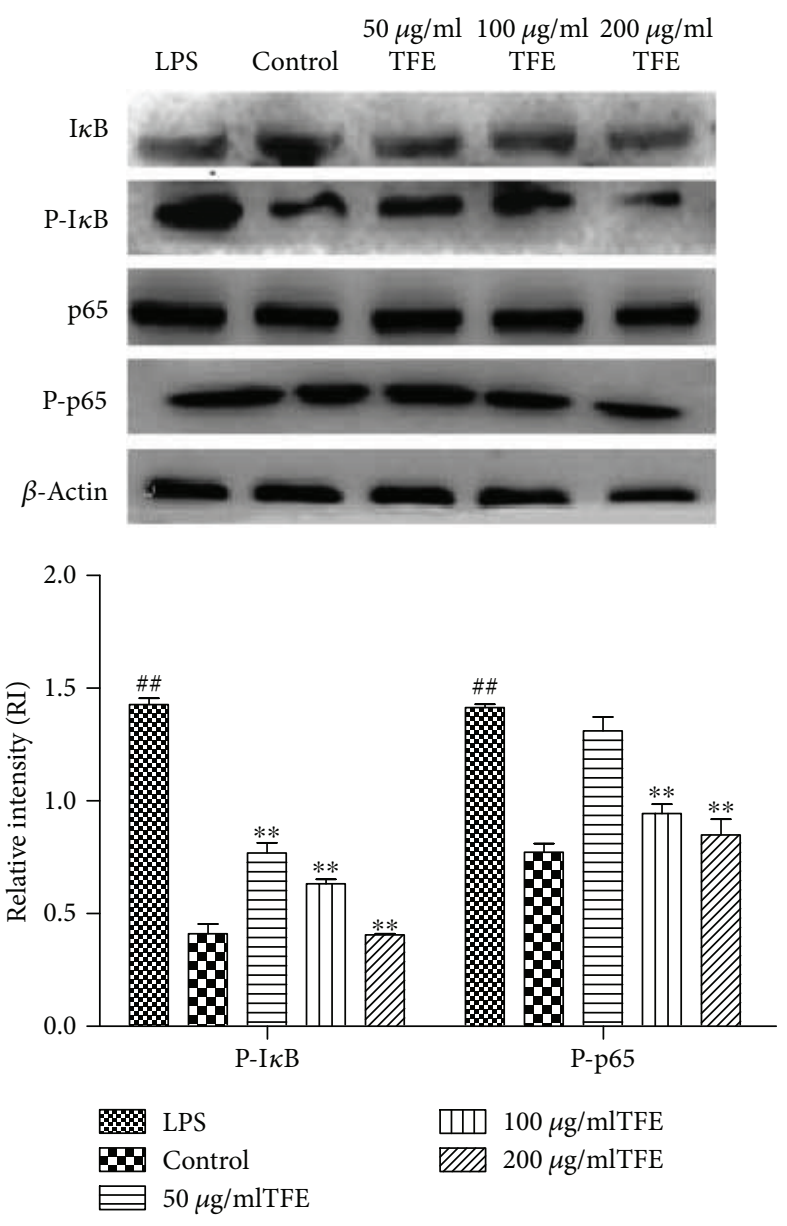

FIGURE 8: Effects of different concentrations of TFE on the proteins expression of $\mathrm{P}-\mathrm{I} \kappa \mathrm{B}$ and $\mathrm{P}-\mathrm{p} 65$ in $\mathrm{NF}-\kappa \mathrm{B}$ signaling pathway in LPS induced RAW 264.7 cells. Cells were pretreated with TFE (50, 100 , and $200 \mu \mathrm{g} / \mathrm{ml})$ for $1 \mathrm{~h}$, followed by LPS $(1 \mu \mathrm{g} / \mathrm{ml})$ stimulation for $18 \mathrm{~h}$. The proteins expression were determined by Western blot analysis, and $\beta$-actin served as an internal control. Values represent the mean \pm SD of the three independent experiments (\#\# compared with the control, ${ }^{* *}$ compared with LPS; **l\#\# $p \leq 0.01)$.

PCR with $\beta$-actin as a reference gene. As shown in Figure 7 , we found that mRNA expression of the $p 65$ gene increased significantly $(p \leq 0.01)$ and that $I \kappa B$ gene expression decreased significantly $(p \leq 0.01)$ in the LPS-induced RAW 264.7 cells compared to the control group. The data indicate that the experimental model was established successfully. Moreover, TFE from A. theophrasti leaves significantly suppresses mRNA expression of the $p 65$ gene $(p \leq 0.01)$ and significantly increases $I \kappa B$ gene expression $(p \leq 0.01)$ compared with the LPS treatment group.

The phosphorylation levels of two important NF- $\kappa \mathrm{B}$ signaling molecules ( $\mathrm{I} \kappa \mathrm{B}$ and $\mathrm{p} 65$ ) were analyzed by Western blot for further clarification of the anti-inflammatory effects of TFE on NF- $\kappa$ B signaling pathways. As shown in Figure 8, the phosphorylation levels of $\mathrm{I} \kappa \mathrm{B}$ and $\mathrm{p} 65$ rose rapidly with treatment by LPS compared with controls. Furthermore, Figure 8 also shows that the degradation of $I \kappa B$ and phosphorylation levels of p65 induced by LPS were inhibited 


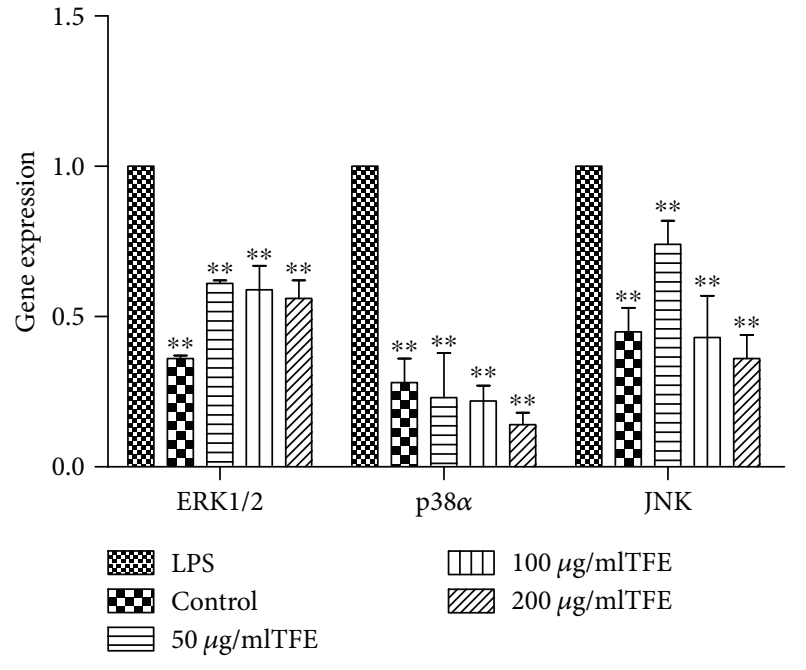

FIGURE 9: Effects of different concentrations of TFE on the genes expression of ERK1/2, p38 $\alpha$, and JNK in MAPK signaling pathway in LPS induced RAW 264.7 cells. Cells were pretreated with TFE (50, 100 , and $200 \mu \mathrm{g} / \mathrm{ml})$ for $1 \mathrm{~h}$, followed by LPS $(1 \mu \mathrm{g} / \mathrm{ml})$ stimulation for $18 \mathrm{~h}$. Values represent the mean \pm SD of the three independent experiments ( ${ }^{*}$ compared with LPS; ${ }^{* * / \# \#} p \leq 0.01$ ).

by TFE in a dose-dependent manner. In addition, the expression of $\mathrm{p}-\mathrm{I} \kappa \mathrm{B}$ was reduced significantly by treatment with 50 , 100 , and $200 \mu \mathrm{g} / \mathrm{ml}$ of TFE. These results indicated that TFE possibly exerts its anti-inflammatory effects by the NF- $\kappa \mathrm{B}$ signaling pathway in LPS-activated RAW 264.7 cells.

3.6.5. Effect of TFE on LPS-Induced MAPK Signaling Pathway Activation. To better understand the mechanisms underlying the anti-inflammatory action, we assessed the effect of TFE from $A$. theophrasti leaves on the MAPK signaling pathways, which are other important signaling pathways for modulating inflammation $[57,58]$. The inhibitory effect of TFE on inflammation was investigated by studying the MAPK signaling pathways. The expression levels of ERK1/2, p38, and $J N K$ genes were examined by real-time fluorescence quantitative PCR, and $\beta$-actin was used as an internal control. As shown in Figure 9, the expression levels of ERK1/2, p38, and $J N K$ mRNA increased significantly after stimulation by LPS $(1 \mu \mathrm{g} / \mathrm{ml})$ compared to those of the control group; they were all significantly suppressed by 50,100 , and $200 \mu \mathrm{g} / \mathrm{ml}$ of TFE compared with those of the LPS treatment group.

To evaluate whether the inhibitory action of TFE on the secretion of inflammatory mediators and cytokines is mediated through the MAPK signaling pathways, the influence of TFE on LPS-stimulated phosphorylation of ERK1/2, JNK, and p38MAPK in RAW 264.7 cells was examined by Western blot analysis with phosphospecific antibodies. Cells were pretreated with 50,100 , and $200 \mu \mathrm{g} / \mathrm{ml}$ of TFE for $1 \mathrm{~h}$ and then stimulated with $1 \mu \mathrm{g} / \mathrm{ml}$ of LPS for $18 \mathrm{~h}$. As shown in Figure 10, the phosphorylation levels of three important MAPK signaling molecules (ERK1/2, JNK, and p38MAPK) were significantly inhibited by different concentrations of TFE. These experimental results indicated that the secretion

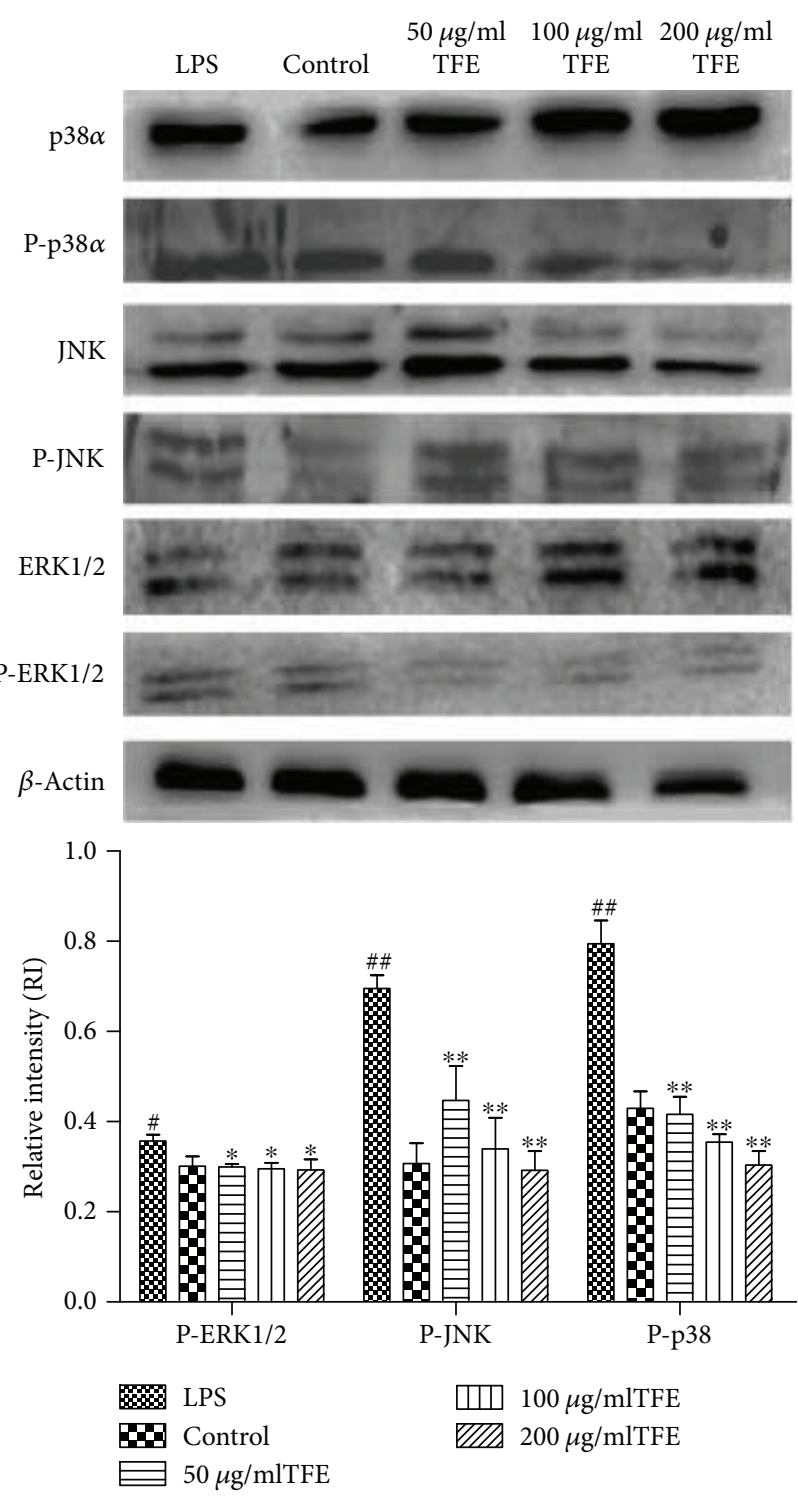

FIGURE 10: Effects of different concentrations of TFE on the proteins expression of P-p38 $\alpha, \mathrm{P}-\mathrm{JNK}$, and P-ERK1/2 in MAPK signaling pathway in LPS induced RAW 264.7 cells. Cells were pretreated with TFE $(50,100$, and $200 \mu \mathrm{g} / \mathrm{ml})$ for $1 \mathrm{~h}$, followed by LPS $(1 \mu \mathrm{g} /$ $\mathrm{ml})$ stimulation for $18 \mathrm{~h}$. The proteins expression were determined by Western blot analysis, and $\beta$-actin served as an internal control. Values represent the mean \pm SD of the three independent experiments ( ${ }^{*}$ compared with the control, ${ }^{*}$ compared with LPS, ${ }^{* / \#} P \leq 0.05$, and $\left.{ }^{* * / \# \#} P \leq 0.01\right)$.

of TNF- $\alpha$, IL- $1 \beta$, and IL- 6 could be inhibited by TFE by blocking the activation of MAPK signaling pathways.

Briefly, NF- $\kappa \mathrm{B}$ and MAPK signaling pathways are considered closely related to the regulation of inflammation by influencing the secretion of proinflammatory cytokines and mediators. LPS, as an inducer, can activate macrophages by stimulating toll-like receptor 4 (TLR4) and triggering NF$\kappa \mathrm{B}$ and MAPK selectively. MyD88 and other small molecule proteins were enriched in toll-like receptors after LPS treatment. In addition, tumor necrosis factor receptor-associated factor 6 (TRAF), a ubiquitin ligase, will produce a series of 


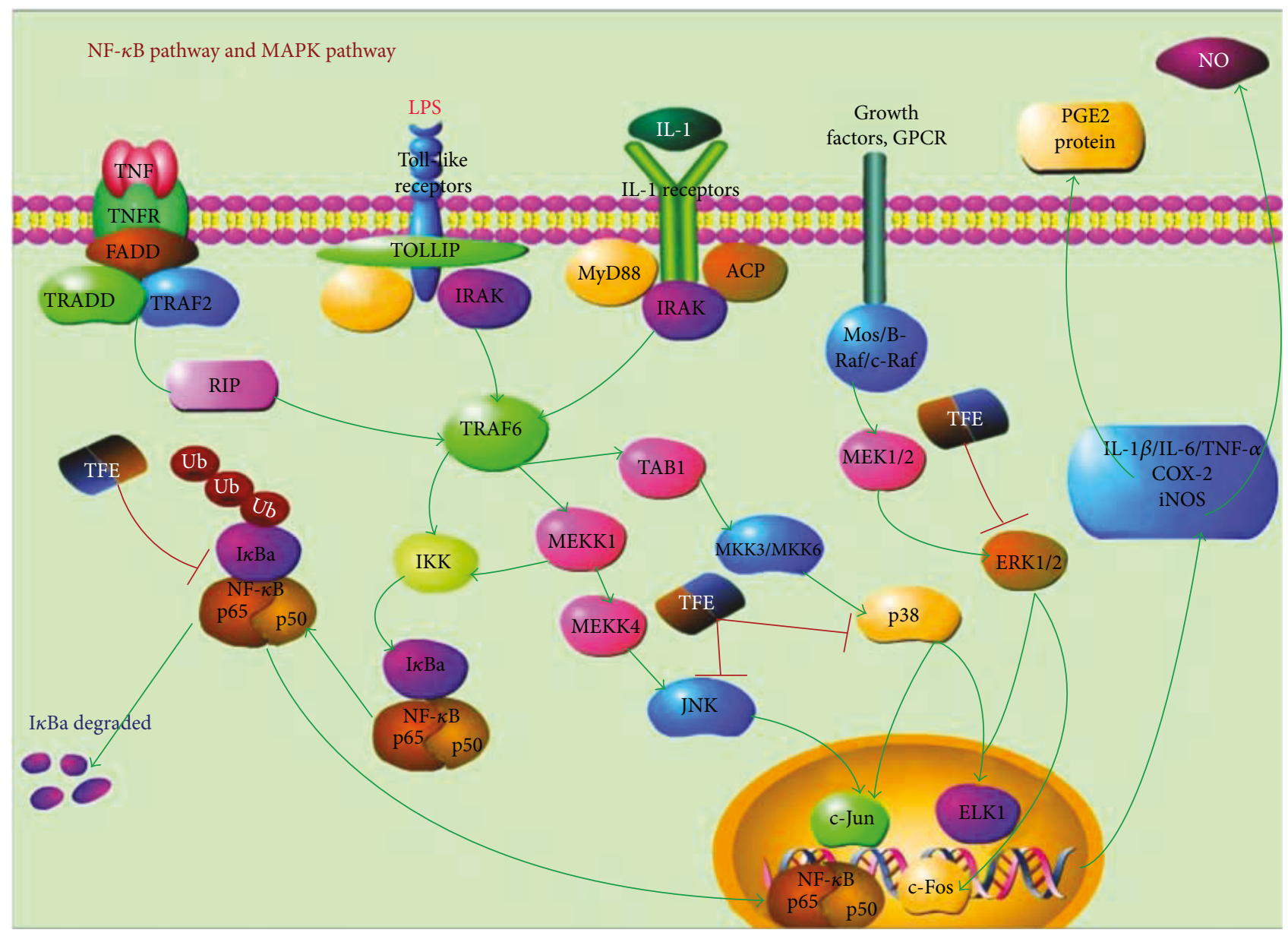

FIGURE 11: The proposed role of TFE on LPS-induced production of proinflammatory mediators and cytokines in RAW 264.7 cells.

related enzymes through ubiquitination reactions. In the NF$\kappa \mathrm{B}$ signaling pathways, I $\kappa \mathrm{B}$ kinase (IKK) can regulate the expression of the downstream genes by degrading $\mathrm{I} \kappa \mathrm{B}$, translocating the p65-p50 dimer into the nucleus and increasing DNA binding sites. As shown in Figure 11, TFE plays an important role in anti-inflammatory activities and not only increases $\mathrm{I} \kappa \mathrm{B}$ gene expression effectively and increases the p65-p50 dimer but also reduces expression of the p65 gene. In the MAPK signaling pathways, TFE clearly displayed anti-inflammation activity via inhibition of phosphorylation of ERK1/2, JNK, and p38MAPK and prevention of their degradation into small molecular fragments and of combination with the DNA-targeted genes.

\section{Conclusion}

In conclusion, this study demonstrated for the first time the specific extraction process, component analysis, and in vitro antioxidant, antibacterial, and anti-inflammatory activities of TFE from A. theophrasti leaves in LPS-stimulated RAW 264.7 cells. The extraction procedure of TFE was optimized by single-factor experimentation and RSM with three variables and three levels, and the extraction conditions were as follows: extraction time $30 \mathrm{~min}$; concentration of ethanol solution $42.28 \%$; and ratio of solvent to material $30: 1 \mathrm{ml} / \mathrm{g}$.
Seven major components of TFE were identified by HPLCDAD-ESI-MS ${ }^{\mathrm{n}}$. In addition, TFE displayed significant antioxidant, antibacterial, and anti-inflammatory activities. It is worth mentioning that TFE exerts anti-inflammatory activities by activation of both NF- $\kappa \mathrm{B}$ and MAPK signaling pathways. However, the effects of TFE on other signaling pathways, such as TLR4 and AP-1, will be investigated in future studies. In addition, future studies will focus on providing additional mechanistic evidence for the effects of TFE on signaling pathways in vivo. Especially noteworthy, TFE from A. theophrasti leaves can be regarded as a new, healthy, and natural drug or additive that is associated with antioxidation and antibacterial and anti-inflammatory activities for the pharmaceutical and food industries.

\section{Ethical Approval}

This article does not contain any studies with human participants or animals performed by any of the authors.

\section{Conflicts of Interest}

The authors have no conflict of interest to declare. 


\section{Authors' Contributions}

Chunlian Tian and Mingchun Liu conceived the study. Xiang Gao, Hong Wang, and Yuru Guo generated the reagents. Chunlian Tian, Peng Zhang, Caixia Yang, and Mingchun Liu participated in the research design. Chunlian Tian, Peng Zhang, Caixia Yang, Xiang Gao, Hong Wang, and Yuru Guo conducted the experiments. Chunlian Tian, Peng Zhang, and Caixia Yang performed the data analysis. Chunlian Tian, Peng Zhang, and Mingchun Liu wrote and contributed to the writing of the manuscript.

\section{Acknowledgments}

The authors are grateful for the financial support from the National Natural Science Foundation of China (Grant no. 31402252) and Youth Foundation of Shenyang Agricultural University (Grant no. 20131001).

\section{References}

[1] E. Z. Gomaa, "In vitro antioxidant, antimicrobial, and antitumor activities of bitter almond and sweet apricot (Prunus armeniaca L.) kernels," Food Science and Biotechnology, vol. 22, no. 2no. 2, pp. 455-463, 2013.

[2] M. Nasri, F. Bedjou, D. Porras, and S. Martínez-Flórez, “Antioxidant, anti-inflammatory, and analgesic activities of Citrus reticulata blanco leaves extracts: an in vivo and in vitro study," Phytothérapie, 2017.

[3] S. Samarghandian, M. Azimi-Nezhad, A. Borji, M. Samini, and T. Farkhondeh, "Protective effects of carnosol against oxidative stress induced brain damage by chronic stress in rats," BMC Complementary and Alternative Medicine, vol. 17, no. 1, p. 249, 2017.

[4] M. Sebastiano, M. Eens, H. Abd Elgawad et al., "Oxidative stress biomarkers are associated with visible clinical signs of a disease in frigatebird nestlings," Scientific Reports, vol. 7, no. 1, p. 1599, 2017.

[5] G. P. Kumar and S. B. Singh, "Antibacterial and antioxidant activities of ethanol extracts from trans Himalayan medicinal plants," European Journal of Applied Science, vol. 3, pp. 53-57, 2011.

[6] A. Zeb, A. Sadiq, F. Ullah, S. Ahmad, and M. Ayaz, "Investigations of anticholinestrase and antioxidant potentials of methanolic extract, subsequent fractions, crude saponins and flavonoids isolated from Isodon rugosus," Biological Research, vol. 47, no. 1, p. 76, 2014.

[7] E. M. Macy and L. H. Chen, "The incidence of anaphylaxis associated with oral and parenteral penicillin-class antibiotic exposures," The Journal of Allergy and Clinical Immunology, vol. 139, no. 2, article AB33, 2017.

[8] N. Urriola, L. Paganini, S. Riminton, and S. Limaye, "Oral amoxicillin-associated anaphylaxis, 1 year after negative penicillin testing and oral amoxicillin challenge," The Journal of Allergy and Clinical Immunology: In Practice, vol. 4, no. 4, pp. 763-764, 2016.

[9] S. Becattini, Y. Taur, and E. G. Pamer, "Antibiotic-induced changes in the intestinal microbiota and disease," Trends in Molecular Medicine, vol. 22, no. 6, pp. 458-478, 2016.

[10] S. F. Plummer, I. Garaiova, T. Sarvotham et al., "Effects of probiotics on the composition of the intestinal microbiota following antibiotic therapy," International Journal of Antimicrobial Agents, vol. 26, no. 1, pp. 69-74, 2005.

[11] V. K. Sharma, N. Johnson, L. Cizmas, T. J. McDonald, and H. Kim, "A review of the influence of treatment strategies on antibiotic resistant bacteria and antibiotic resistance genes," Chemosphere, vol. 150, pp. 702-714, 2016.

[12] P. Vassal, P. Berthelot, J. P. Chaussinandc et al., "Extensively drug-resistant bacteria: which ethical issues? Bactéries hautement résistantes émergentes: quels enjeux éthiques?," Médecine et Maladies Infectieuses, vol. 47, no. 5, pp. 319-323, 2017.

[13] S. J. Kim, K. T. Lee, H. E. Choi et al., "Anti-inflammatory effects of flavonoids in Korean Chrysanthemum species via suppression of inducible nitric oxide synthase and cyclooxygenase-2 in LPS-induced RAW 264.7 macrophages," Food Science and Biotechnology, vol. 24, no. 3, pp. 975-985, 2015.

[14] A. Y. Lee, S. L. Lee, H. Y. Kim, S. H. Lee, and E. J. Cho, "Anti-inflammatory effects of luteolin and luteoloside from Taraxacum coreanum in RAW264.7 macrophage cells," Applied Biological Chemistry, vol. 59, no. 5, pp. 747-754, 2016.

[15] L. Z. Yi, S. S. Ma, and D. B. Ren, "Phytochemistry and bioactivity of citrus flavonoids: a focus on antioxidant, anti-inflammatory, anticancer and cardiovascular protection activities," Phytochemistry Reviews, vol. 16, no. 3, pp. 479-511, 2017.

[16] W. Marlicz, L. Łoniewski, D. S. Grimes, and E. M. Quigley, "Nonsteroidal anti-inflammatory drugs, proton pump inhibitors, and gastrointestinal injury: contrasting interactions in the stomach and small intestine," Mayo Clinic Proceedings, vol. 89, no. 12, pp. 1699-1709, 2014.

[17] D. Mehta and D. K. Bhargava, "Non-steroidal anti inflammatory drugs and gastrointestinal toxicity," Apollo Medicine, vol. 7, no. 4, pp. 251-262, 2010.

[18] M. V. Aun, M. Blanca, L. S. Garro et al., "Nonsteroidal antiinflammatory drugs are major causes of drug-induced anaphylaxis," The Journal of Allergy and Clinical Immunology: In Practice, vol. 2, no. 4, pp. 414-420, 2014.

[19] K. G. Blumenthal, K. H. Lai, M. S. Huang, Z. S. Wallace, P. G. Wickner, and L. Zhou, "Adverse and hypersensitivity reactions to prescription nonsteroidal anti-inflammatory agents in a large health care system," The Journal of Allergy and Clinical Immunology: In Practice, vol. 5, no. 3, pp. 737-743.e3, 2017.

[20] M. Kuruvilla and D. A. Khan, "Anaphylaxis to drugs," Immunology and Allergy Clinics of North America, vol. 35, no. 2, pp. 303-319, 2015.

[21] C. D. Fu and Y. F. Hong, "Research on chemical composition of Abutilon theophrasti Medic," Foreign Medicine Science, vol. 15, pp. 4-7, 1993.

[22] K. M. Shi, C. Y. Li, C. Li, X. He, Z. C. Lu, and C. J. Zhao, "Progress of study on constituents of Abutilon theophrasti Medic," Heilongjiang Medicine Journal, vol. 28, no. 2, pp. 224-227, 2015.

[23] M. Sikorska and I. Matlawska, "Polyphenolic compounds from Abutilon grandiflorum leaves," Acta Poloniae PharmaceuticaDrug Research, vol. 65, pp. 467-471, 2008.

[24] C. L. Tian, M. Wang, C. H. Sheng, and C. J. Zhao, “Accuracy mass screening and identification of phenolic compounds from the five parts of Abutilon theophrasti Medic. by reversephase high-performance liquid chromatography - electrospray ionization - quadrupoles - time of flight - mass spectrometry," Journal of Separation Science, vol. 35, no. 5-6, pp. 763-772, 2012. 
[25] G. Y. Gu and Y. Jiang, "Research on chemical composition and pharmacological action of Abutilon indicum and Abutilon," Modern Pharmacy and Clinic, vol. 24, pp. 338-340, 2009.

[26] H. Liu, S. F. Ni, J. H. Kang et al., "The pharmaceutical research situation of plants of Abutilon," Northwest Pharmaceutical Journal, vol. 25, pp. 68-69, 2010.

[27] L. J. Su, L. H. Yang, X. M. Zhang, and W. P. Zhang, “Antiinflammatory analgesic active site research of the stems and leaves of Abutilon theophrasti Medic," China Science and Technology of Chinese Medicine, vol. 17, p. 314, 2010.

[28] H. M. Awad, H. I. Abd-Alla, K. H. Mahmoud, and S. A. El-Toumy, "In vitro anti-nitrosative, antioxidant, and cytotoxicity activities of plant flavonoids: a comparative study," Medicinal Chemistry Research, vol. 23, no. 7, pp. 3298-3307, 2014.

[29] M. Chakraboty, A. Bala, and P. K. Haldar, "Flavonoid enriched fraction of Campylandra aurantiaca attenuates carbon tetrachloride induced oxidative DNA damage in mouse peritoneal macrophages in animal model," Current Drug Discovery Technologies, vol. 14, no. 4, pp. 270-276, 2017.

[30] P. Hikisz, K. Szczupak, A. Koceva-Chyka et al., "Anticancer and antibacterical activity studies of gold(I)-alkynyl chromones," Molecules, vol. 20, no. 12, pp. 19699-19718, 2015.

[31] H. J. Kim, H. J. Jeong, J. W. Hong, E. S. Ju, C. S. Kong, and Y. W. Seo, "Evaluation of flavonoids from Zostera asiatica as antioxidants and nitric oxide inhibitors," Biotechnology and Bioprocess Engineering, vol. 21, no. 6, pp. 823-829, 2016.

[32] W. J. Kong, Y. L. Zhao, X. Y. Xing et al., "Antibacterial evaluation of flavonoid compounds against $E$. coli by microcalorimetry and chemometrics," Applied Microbiology and Biotechnology, vol. 99, no. 14, pp. 6049-6058, 2015.

[33] L. M. Li, J. Zhou, J. Lou et al., "A new flavone from stems of Garcinia bracteata and its anti-TMV activity," China Journal of Chinese Materia Medica, vol. 40, no. 21, pp. 4205-4207, 2015.

[34] G. W. Zhang, L. He, and M. M. Hu, "Optimized ultrasonicassisted extraction of flavonoids from Prunella vulgaris L. and evaluation of antioxidant activities in vitro," Innovative Food Science and Emerging Technologies, vol. 12, no. 1, pp. 18-25, 2011.

[35] A. L. Dawidowicz and M. Olszowy, "The importance of solvent type in estimating antioxidant properties of phenolic compounds by ABTS assay," European Food Research and Technology, vol. 236, no. 6, pp. 1099-1105, 2013.

[36] A. L. Dawidowicz, M. Olszowy, and M. Jóźwik-Dolęba, "Importance of solvent association in the estimation of antioxidant properties of phenolic compounds by DPPH method," Journal of Food Science and Technology, vol. 52, no. 7, pp. 4523-4529, 2015.

[37] P. Pajak, R. Socha, D. Gałkowska, J. Roznowski, and T. Fortuna, "Phenolic profile and antioxidant activity in selected seeds and sprouts," Food Chemistry, vol. 143, pp. 300-306, 2014.

[38] N. Jaradat, L. Adwan, S. K'aibni, N. Shraim, and A. N. Zaid, "Chemical composition, anthelmintic, antibacterial and antioxidant effects of Thymus bovei essential oil," BMC Complementary and Alternative Medicine, vol. 16, no. 1, p. 418, 2016.

[39] B. Kim, J. H. Lee, S. Myung-J, S. H. Eom, and W. Kim, "Linarin down-regulates phagocytosis, pro-inflammatory cytokine production, and activation marker expression in RAW264.7 macrophages," Food Science and Biotechnology, vol. 25, no. 5, pp. 1437-1442, 2016.

[40] K. Y. Su, C. Y. Yu, Y. P. Chen, K. F. Hua, and Y. L. S. Chen, "3,4-Dihydroxytoluene, a metabolite of rutin, inhibits inflammatory responses in lipopolysaccharide-activated macrophages by reducing the activation of NF- $\kappa \mathrm{B}$ signaling," $B M C$ Complementary and Alternative Medicine, vol. 14, no. 1, p. 21, 2014.

[41] J. Y. Jang, M. J. Lee, B. R. You et al., “Allium hookeri root extract exerts anti-inflammatory effects by nuclear factor- $\kappa \mathrm{B}$ down-regulation in lipopolysaccharide induced RAW264.7 cells," BMC Complementary and Alternative Medicine, vol. 17, no. 1, p. 126, 2017.

[42] L. Guo, W. C. Zhu, Y. T. Liu, J. Y. Wu, A. Q. Zheng, and Y. L. Liu, "Response surface optimized extraction of flavonoids from mimenghua and its antioxidant activities in vitro," Food Science and Biotechnology, vol. 22, no. 5, pp. 1-8, 2013.

[43] X. F. Shi, D. Y. Liu, J. M. Zhang et al., "Extraction and purification of total flavonoids from pine needles of Cedrus deodara contribute to anti-tumor in vitro," BMC Complementary and Alternative Medicine, vol. 16, no. 1, p. 245, 2016.

[44] R. Upadhyay, G. Nachiappan, and H. N. Mishra, "Ultrasoundassisted extraction of flavonoids and phenolic compounds from Ocimum tenuiflorum leaves," Food Science and Biotechnology, vol. 24, no. 6, pp. 1951-1958, 2015.

[45] C. L. Tian, D. X. Zhang, C. X. Yang, Z. M. Chen, and M. C. Liu, "Research on extraction technology, antibacterial and antioxidant activity of ethanol extract from leaves of Abutilon theophrasti Medic," Acta Poloniae Pharmaceutica - Drug Research, vol. 74, no. 3, pp. 881-890, 2017.

[46] D. Adinarayana and M. Sarada, "Phytochemical study of Indigofera mysorensis Rottl. leaves," Journal of the Indian Chemical Society, vol. 64, pp. 648-649, 1987.

[47] E. H. Fernández, A. C. Pancorbo, and A. F. Gutiérrez, "Profiling LC-DAD-ESI-TOF MS method for the determination of phenolic metabolites from avocado (Persea americana)," Journal of Agricultural and Food Chemistry, vol. 59, no. 6, pp. 2255-2267, 2011.

[48] Y. L. Feng, L. Z. Xu, S. L. Yang, and Z. M. Zou, "Chemical constituents isolated from flowers of Althaea rosea," Chinese Traditional and Herbal Drugs, vol. 11, pp. 1610-1612, 2005.

[49] I. Matlawska and M. Sikorska, "Flavonoids from Abutilon theophrasti flowers," Acta Poloniae Pharmaceutica, vol. 62, no. 2, pp. 135-139, 2005.

[50] S. C. Shen, W. R. Lee, H. Y. Lin et al., "In vitro and in vivo inhibitory activities of rutin, wogonin, and quercetin on lipopolysaccharide-induced nitric oxide and prostaglandin $\mathrm{E}_{2}$ production," European Journal of Pharmacology, vol. 446, no. 1-3, pp. 187-194, 2002.

[51] K. J. Woo, J. H. Lim, S. I. Suh et al., "Differential inhibitory effects of baicalein and baicalin on LPS-induced cyclooxygenase- 2 expression through inhibition of $\mathrm{C} / \mathrm{EBP} \beta$ DNA-binding activity," Immunobiology, vol. 211, no. 5, pp. 359-368, 2006.

[52] G. C. Huang, J. M. Chow, S. C. Shen, L. Y. Yang, C. W. Lin, and Y. C. Chen, "Wogonin but not norwogonin inhibits lipopolysaccharide and lipoteichoic acid-induced iNOS gene expression and NO production in macrophages," International Immunopharmacology, vol. 7, no. 8, pp. 1054-1063, 2007.

[53] H. M. Abdallah, F. M. Almowallad, A. Esmat, I. A. Shehata, and E. A. Abdel-Sattar, "Anti-inflammatory activity of 
flavonoids from Chrozophora tinctoria," Phytochemistry Letters, vol. 13, pp. 74-80, 2015.

[54] N. Nakamura, S. J. Hayasaka, X. Y. Zhang et al., "Effects of baicalin, baicalein, and wogonin on interleukin-6 and interleukin- 8 expression, and nuclear factor- $\kappa$ b binding activities induced by interleukin-1 $\beta$ in human retinal pigment epithelial cell line," Experimental Eye Research, vol. 77, no. 2, pp. 195-202, 2003.

[55] L. Cao, R. T. Li, X. Q. Chen, Y. Xue, and D. Liu, "Neougonin A inhibits lipopolysaccharide-induced inflammatory responses via downregulation of the NF- $\kappa$ B signaling pathway in RAW 264.7 macrophages," Inflammation, vol. 39, no. 6, pp. 19391948, 2016.

[56] G. W. Fan, X. R. Jiang, X. Y. Wu et al., "Anti-inflammatory activity of tanshinone IIA in LPS-stimulated RAW264.7 macrophages via miRNAs and TLR4-NF- $\kappa$ B pathway," Inflammation, vol. 39, no. 1, pp. 375-384, 2016.

[57] Y. A. Seong, D. Hwang, and G. D. Kim, "The antiinflammatory effect of gnaphalium affine through inhibition of NF- $\kappa \mathrm{B}$ and MAPK in lipopolysaccharide-stimulated RAW264.7 cells and analysis of its phytochemical components," Cell Biochemistry and Biophysics, vol. 74, no. 3, pp. 407-417, 2016.

[58] J. Y. Tao, Y. Y. Wei, and T. J. Hu, "Flavonoids of polygonum hydropiper 1. attenuates lipopolysaccharide-induced inflammatory injury via suppressing phosphorylation in MAPKs pathways," BMC Complementary and Alternative Medicine, vol. 16, no. 1, p. 25, 2015. 


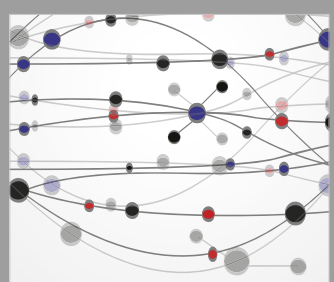

The Scientific World Journal
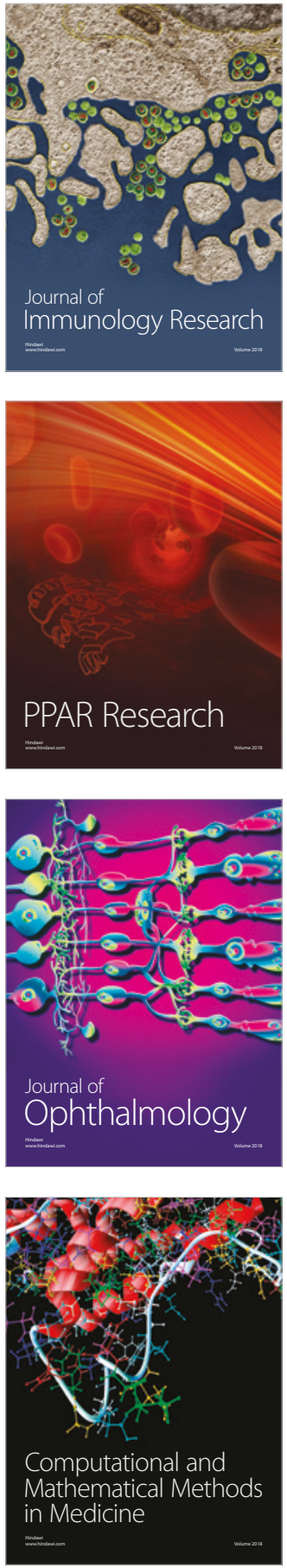

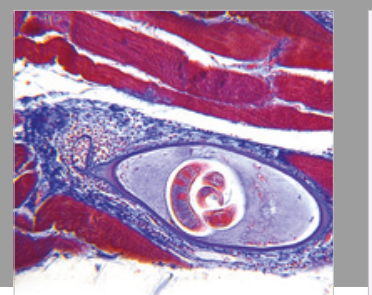

Gastroenterology Research and Practice

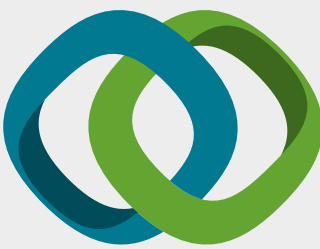

\section{Hindawi}

Submit your manuscripts at

www.hindawi.com
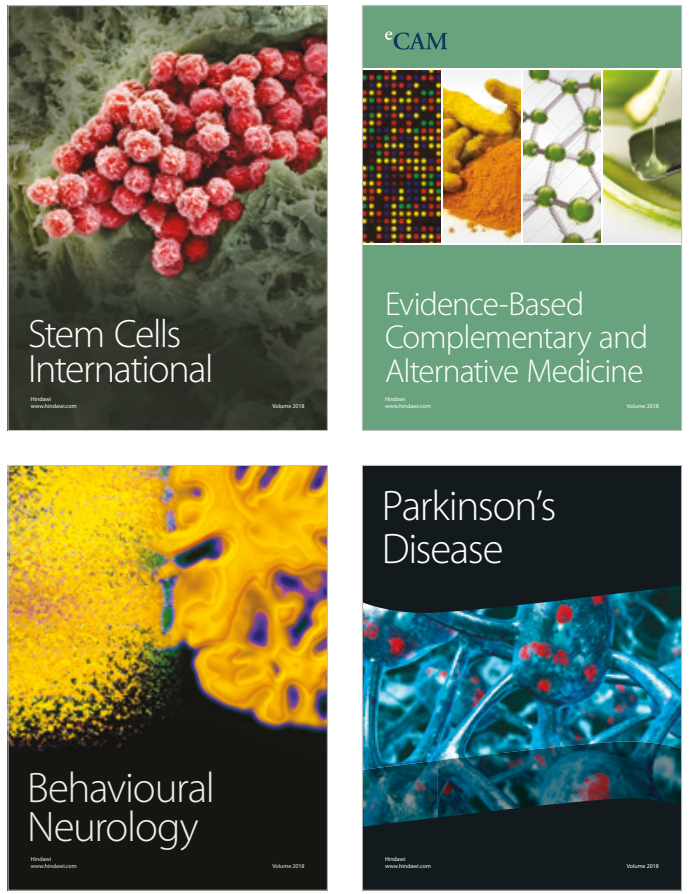

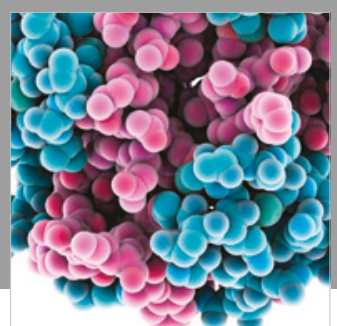

ournal of

Diabetes Research

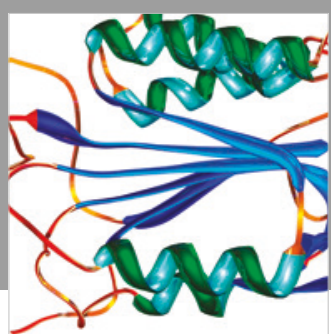

Disease Markers
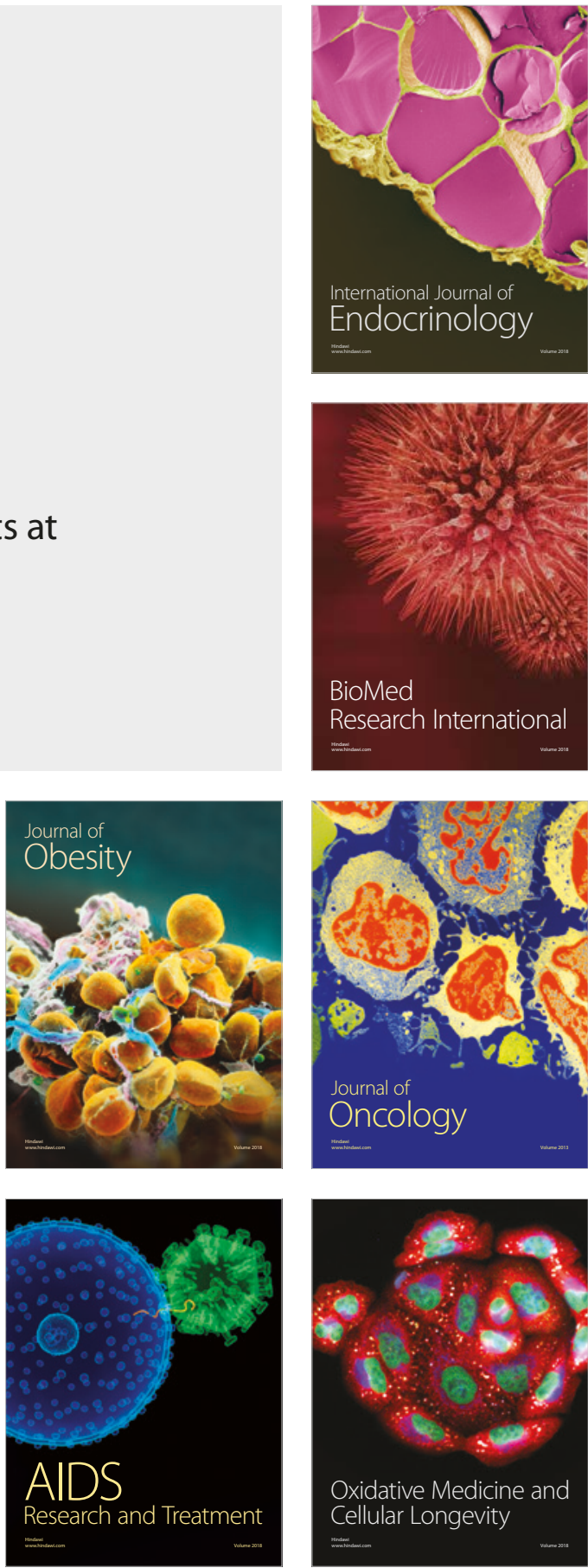